Article

\title{
Aryloxyalkanoic Acids as Non-Covalent Modifiers of the Allosteric Properties of Hemoglobin
}

\author{
Abdelsattar M. Omar 1,2, , Mona A. Mahran ${ }^{3}$, Mohini S. Ghatge ${ }^{4}$, Faida H. A. Bamane ${ }^{5}$, \\ Mostafa H. Ahmed ${ }^{4}$, Moustafa E. El-Araby ${ }^{1,6}$, Osheiza Abdulmalik ${ }^{7}$ and Martin K. Safo ${ }^{4, *}$ \\ 1 Department of Pharmaceutical Chemistry, Faculty of Pharmacy, King Abdulaziz University, Alsulaymanyah, \\ Jeddah 21589, Saudi Arabia; alamka@gmail.com \\ 2 Department of Pharmaceutical Chemistry, Faculty of Pharmacy, Al-Azhar University, Cairo 11884, Egypt \\ 3 Department of Pharmaceutical Chemistry, Faculty of Pharmacy, Alexandria University, Alexandria 21521, \\ Egypt; mahranmona@yahoo.com \\ 4 Department of Medicinal Chemistry, and The Institute for Structural Biology, Drug Discovery and \\ Development, School of Pharmacy, Virginia Commonwealth University, Richmond, VA 23298, USA; \\ msghatge@vcu.edu (M.S.G.); ahmedmh@vcu.edu (M.H.A.) \\ 5 Department of Biochemistry, Faculty of Medicine, King Abdulaziz University, Alsulaymanyah, \\ Jeddah 21589, Saudi Arabia; fbamane@yahoo.com \\ 6 Department of Pharmaceutical Organic Chemistry, Faculty of Pharmacy, Helwan University, \\ Cairo 11790, Egypt \\ 7 Division of Hematology, The Children's Hospital of Philadelphia, Philadelphia, PA 19104, USA; \\ abdulmalik@email.chop.edu \\ * Correspondence: asmansour@kau.edu.sa (A.M.O.); msafo@vcu.edu (M.K.S.); \\ Tel.: +966-567-68-14-66 (A.M.O.); +1-804-828-7291 (M.K.S.)
}

Academic Editor: Derek J. McPhee

Received: 27 June 2016; Accepted: 9 August 2016; Published: 13 August 2016

\begin{abstract}
Hemoglobin $(\mathrm{Hb})$ modifiers that stereospecifically inhibit sickle hemoglobin polymer formation and/or allosterically increase $\mathrm{Hb}$ affinity for oxygen have been shown to prevent the primary pathophysiology of sickle cell disease (SCD), specifically, $\mathrm{Hb}$ polymerization and red blood cell sickling. Several such compounds are currently being clinically studied for the treatment of SCD. Based on the previously reported non-covalent $\mathrm{Hb}$ binding characteristics of substituted aryloxyalkanoic acids that exhibited antisickling properties, we designed, synthesized and evaluated 18 new compounds (KAUS II series) for enhanced antisickling activities. Surprisingly, select test compounds showed no antisickling effects or promoted erythrocyte sickling. Additionally, the compounds showed no significant effect on $\mathrm{Hb}$ oxygen affinity (or in some cases, even decreased the affinity for oxygen). The X-ray structure of deoxygenated $\mathrm{Hb}$ in complex with a prototype compound, KAUS-23, revealed that the effector bound in the central water cavity of the protein, providing atomic level explanations for the observed functional and biological activities. Although the structural modification did not lead to the anticipated biological effects, the findings provide important direction for designing candidate antisickling agents, as well as a framework for novel $\mathrm{Hb}$ allosteric effectors that conversely, decrease the protein affinity for oxygen for potential therapeutic use for hypoxic- and/or ischemic-related diseases.
\end{abstract}

Keywords: hemoglobin; sickle cell disease; aryloxyalkanoic acids; halogenated benzene; imidazole; antisickling; oxygen equilibrium curve; high affinity; low affinity; crystal structure 


\section{Introduction}

In its function of transporting oxygen from the lungs to tissues, hemoglobin $(\mathrm{Hb})$ alternates between tense or T-state (unliganded or deoxygenated $\mathrm{Hb}$ ) and the relaxed or R-state (liganded or oxygenated $\mathrm{Hb}$ ). The equilibrium between the two states can be regulated by synthetic allosteric effectors that bind to the central water cavity or the surface of the protein [1,2]. Stabilization of the R-state and/or destabilization of the T-state shifts $\mathrm{Hb}$ oxygen equilibrium curve (OEC) to the left, producing a high-affinity $\mathrm{Hb}$ that is known to be beneficial for sickle cell disease (SCD) therapy $[1,2]$. The converse, where a low-affinity $\mathrm{Hb}$ is produced with OEC right-shifting compounds that are also potentially useful for the treatment of hypoxic- and/or ischemic-related diseases is also true [1,2]. Under hypoxia sickle $\mathrm{Hb}(\mathrm{Hb} \mathrm{S})$ polymerizes into long, rigid, and insoluble fibers causing the primary pathophysiology associated with SCD, which leads to RBC sickling, vaso-occlusion, painful crises, organ damage, oxidative stress, hemolysis of RBCs, decreased vascular NO bioavailability, inflammation, impaired microvascular blood flow, morbidity and even mortality [3-6]. The polymerization process is exacerbated by the low oxygen affinity of $\mathrm{Hb} \mathrm{S}$, presumably as a result of unusually high concentration of 2,3-diphosphoglycerate and/or sphingosine phosphate in sickle red blood cells (RBC) [7-10]. The polymer is initiated by a primary interaction between the pathological $\beta 2 \mathrm{Val} 6$ from one $\mathrm{Hb} \mathrm{S}$ molecule and a hydrophobic acceptor pocket in the region of $\beta 1$ Ala70, $\beta 1$ Phe 85 and $\beta 1$ Leu 88 of another $\mathrm{Hb}$ molecule, and further stabilized by several secondary contacts between the $\mathrm{Hb}$ molecules [11-15]. Disruption or weakening of the secondary contacts is known to reduce $\mathrm{Hb} \mathrm{S}$ polymerization and $\mathrm{RBC}$ sickling as demonstrated by a large number of naturally occurring mutations that are known to mitigate the severity of SCD [16,17].

There have been several efforts to develop pharmacological interventions that increase $\mathrm{Hb}$ oxygen affinity to prevent the hypoxia-induced $\mathrm{Hb} \mathrm{S}$ polymerization and/or directly destabilize polymer contacts $[1,2,10]$. The most promising are covalent modifiers of $\mathrm{Hb}$, with examples such as aromatic aldehydes [18-21], ethacrynic acid derivatives [22], isothiocynates [23], and thiols [24]. Nonetheless nonspecific binding to other proteins and the resulting toxic effects has precluded several of these covalent modifiers from being considered as therapeutic agents [10]. Abraham and co-workers in the eighties showed that halogenated benzene derivatives or substituted aryloxyalkanoic acids bind non-covalently to $\mathrm{Hb}$ at multiple $\mathrm{Hb}$ sites, including the central water cavity or the $\mathrm{CD}$-corner or the $\alpha \operatorname{Trp} 14$ binding pocket at the surface of the protein [25-29]. Those compounds that bind exclusively to the CD-corner or $\alpha \operatorname{Trp} 14$ site, e.g., 3,4-(dichlorobenzyl)oxyacetic acid or $p$-(bromobenzyl)oxyacetic acid showed no significant effect on $\mathrm{Hb}$ oxygen binding properties, however they exhibited weak antisickling effect, which was speculated to be due to weakening or destabilization of the polymer contacts [25-28]. On the other hand, compounds, e.g., clofibrate and several of its analogs or derivatives that bind to the central water cavity decreased $\mathrm{Hb}$ affinity for oxygen due to stabilization of T-state $\mathrm{Hb}$ [25-32]. Although, compounds that decrease $\mathrm{Hb}$ affinity for oxygen are expected to promote hypoxia-induced sickling, clofibrate was reported to exhibit a weak antisickling effect, which was attributed to the compound also binding to the $\alpha \operatorname{Trp} 14$ site beside the central water cavity to destabilize the polymer [27].

Even though the reported $\alpha \operatorname{Trp} 14$ binders showed marginal antisickling effects, the $\alpha \operatorname{Trp} 14$ site remains an attractive target for drug design, which we decided to investigate. Consequently, we have structurally modified the previously studied aryloxyalkanoic acid pharmacophore into two series of compounds, 4-(imidazole-2-carbonyl)phenoxyalkanoic acids (7a-I; KAUS-1 to KAUS-8) and 4-(imidazol-2-yl)phenoxyalkanoic acids (13, 17a-e, 21a-c; KAUS-20 to KAUS-27) that are expected to bind to the $\alpha \operatorname{Trp} 14$ site. The compounds have been tested for their effect on both sickle RBC morphology and $\mathrm{Hb}$ oxygen binding properties. One of the compounds, KAUS- 23 was co-crystallized with deoxygenated $\mathrm{Hb}$ and its binding mode studied to gain insight into the compound's functional and biological activities. 


\section{Results and Discussion}

\subsection{Compounds Designed to Bind at the $\alpha$ Trp14 Site of Hemoglobin}

Substituted aromatic compounds, e.g., aryloxyalkanoic acids, have been shown to bind non-covalently to $\mathrm{Hb}$ at the central water cavity or the surface of the protein, e.g., $\alpha \operatorname{Trp} 14$ or CD-corner binding sites and display moderate or no antisickling effect, and in some instances even prosickling effects [22-25,29]. In most cases, the compounds that bind exclusively to the central water cavity showed no antisickling activity, due to stabilization of T-state $\mathrm{Hb}$ and the concomitant decrease in $\mathrm{Hb}$ affinity for oxygen $[25,27,28]$. In contrast, compounds that bind to the surface of the protein, e.g., the $\alpha \operatorname{Trp} 14$ binding pocket exhibited moderate antisickling activities, which was attributed to direct polymer destabilization [25-28]. Other aryloxyalkanoic acids, e.g., clofibrate (Figure 1) which is known to bind to both the central water cavity and the $\alpha \operatorname{Trp} 14$ site was reported to show both low-oxygen affinity and antisickling properties [27].

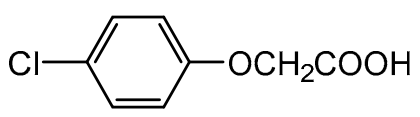

\section{Clofibric acid (CFA)}

Figure 1. Example of previously studied aryloxyalkanoic acid derivatives.

The $\alpha \operatorname{Trp} 14$ binding pocket is lined with several hydrophobic residues, including $\alpha \operatorname{Trp} 14, \alpha$ Val17, $\alpha$ Ala21, $\alpha$ Tyr24, $\alpha$ Phe128, $\alpha$ Leu105, $\alpha$ Leu109 and $\alpha$ Leu125, and hydrophilic residues at the mouth of the cavity including, $\alpha$ Thr67, $\alpha$ Lys11 and $\alpha$ Lys60. The crystal structures of deoxygenated $\mathrm{Hb}$ in complex with 3,4-(dichlorobenzyl)oxyacetic acid or clofibrate or other aryloxyalkanoic acids that bind to the $\alpha \operatorname{Trp} 14$ have been described previously [25-29]. Due to the low resolution nature of the structures, detailed interactions between the protein and compounds were not described, however the interactions with the surrounding hydrophobic residues were suggested to be predominantly hydrophobic and dipolar van der Waals in nature [25-28]. These compounds presumably bind similarly to the $\alpha \operatorname{Trp} 14$ pocket like the toluene molecule whose coordinates are available from a more recently determined high-resolution structure (PDB code 1R1X)[33]. In this structure, the $\alpha$ Trp14 pocket shows two bound toluene molecules making hydrophobic interactions with $\alpha \operatorname{Trp} 14, \alpha \operatorname{Val17,} \alpha \operatorname{Tyr} 24, \alpha \operatorname{Thr67}$, $\alpha$ Lue105, $\alpha$ Leu109, $\alpha$ Leu125, $\alpha$ Phe128, $\alpha$ Val10, $\alpha$ Val70 and $\alpha$ Leu66 (Figure 2a).

Based on the $\alpha \operatorname{Trp} 14$ binding interactions with 3,4-[(dichlorobenzyl)oxy]acetic acid or clofibrate and the fact that two toluene molecules are able to fit the binding cavity (Figure 2a), we hypothesized that increasing the size of the aryloxyalkanoic acids for additional hydrophobic interactions with the $\alpha \operatorname{Trp} 14$ pocket residues might lead to stronger compound binding, resulting in increased $\mathrm{Hb}$ affinity for oxygen and antisickling potency. We therefore embarked on a series of structural modifications of the aryloxyalkanoic acid pharmacophore by introducing an imidazole to the aryloxyalkanoic ring that we anticipate will increase hydrophobic interaction with the $\alpha \operatorname{Trp} 14$ non-polar pocket residues as putatively illustrated in Figure $2 b$ (please see Supplementary Material for a description of the docking process). 


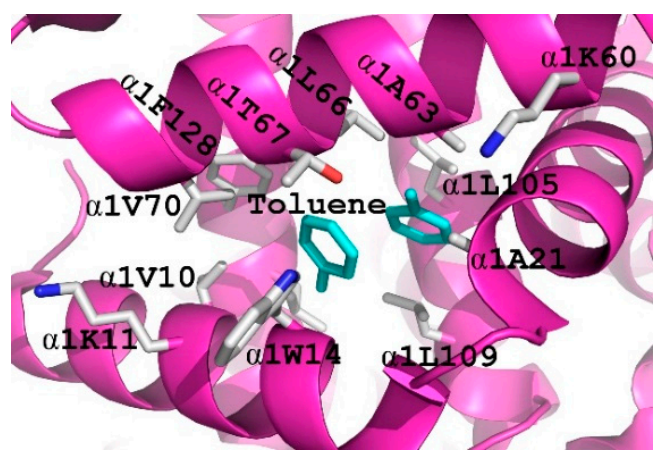

(a)

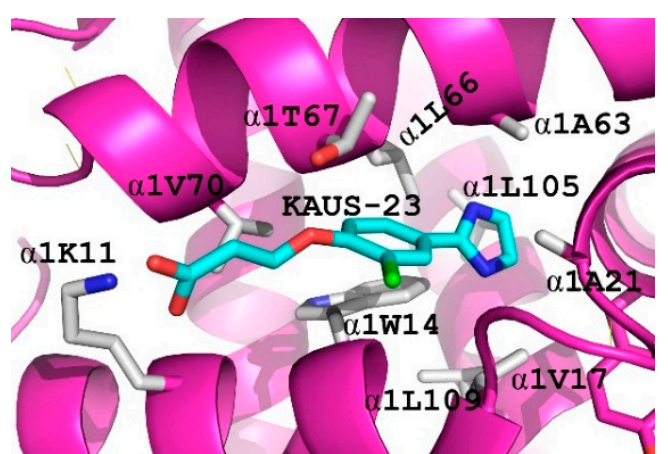

(b)

Figure 2. The $\alpha \operatorname{Trp} 14$ binding pocket. (a) Binding of two molecules of toluene at the $\alpha \operatorname{Trp} 14$ binding pocket of carbonmonoxy $\mathrm{Hb}$ (PDB ID: 1R1X). As noted in the text, CFA binds in a similar fashion but the coordinate is not available [27]; (b) Putative binding of KAUS-23 at the Trp14 binding pocket of deoxygenated $\mathrm{Hb}$ (PDB ID: 2DN2).

Two classes of compounds, (imidazole-2-carbonyl)phenoxyalkanoic acids (7a-I; KAUS-1 to KAUS-8) and (imidazol-2-yl)phenoxyalkanoic acids (13, 17a-e, 21a-c; KAUS-20 to KAUS-27) were synthesized. The proposed compounds, like 3,4-(dichlorobenzyl)oxyacetic acid and clofibrate also contain carboxylate moieties that could potentially form salt-bridge/hydrogen-bond interactions with $\alpha$ Lys60 and/or $\alpha$ Thr67 located at the mouth of the pocket (Figure $2 b$ ). We should point out that there is no indication to suggest that the carboxylate of 3,4-(dichlorobenzyl)oxyacetic acid or clofibrate form such polar interactions. It was also anticipated that the compounds will exhibit minimal toxicity effect due to their non-covalent interactions with $\mathrm{Hb}$ compared to compounds that bind covalently to $\mathrm{Hb}$. Each class of the proposed compound can further be subdivided into three subclasses that differ in their carboxylate arm length. Compounds in each subclass also differ in the number or position of the chloro substituents on the phenoxyalkanoic ring. The synthetic pathways adopted for the preparation of the intermediate and target compounds are outlined in Schemes 1-5 and detailed syntheses are described in the Experimental Section. The compounds were then tested for their effect on sickle RBC morphology and $\mathrm{Hb}$ oxygen affinity.

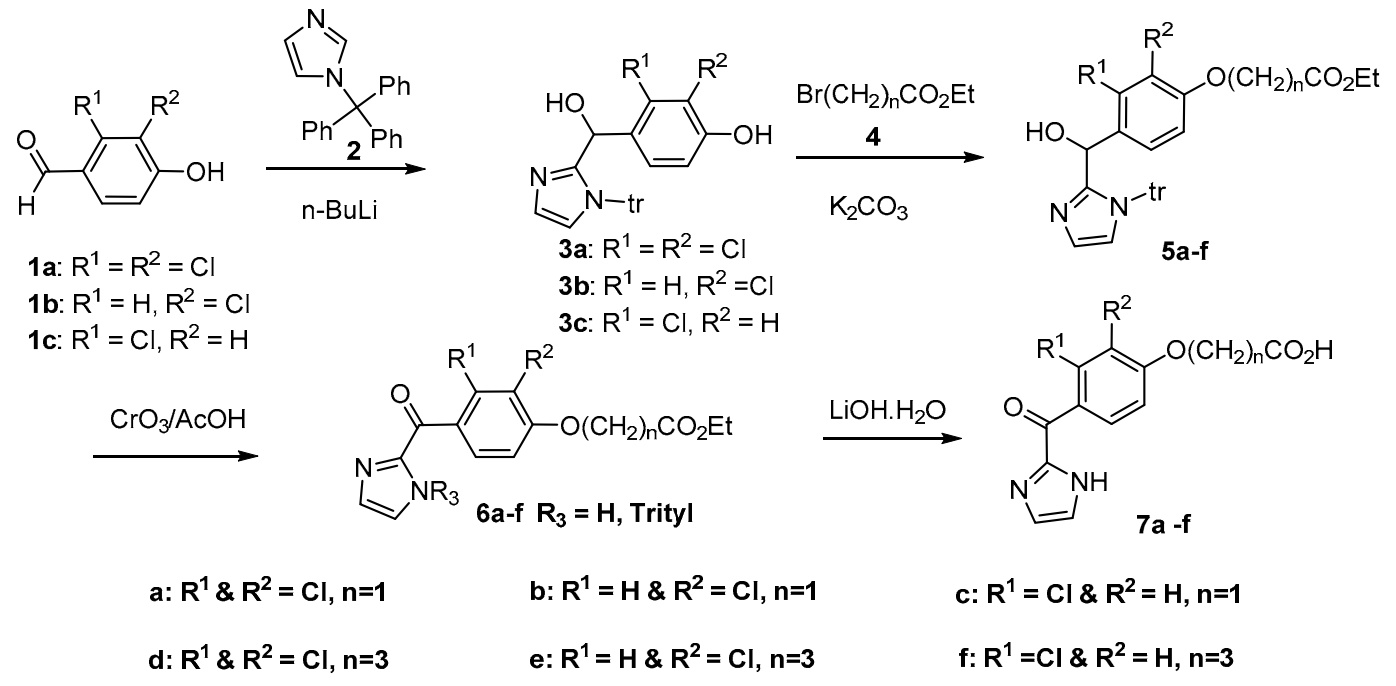

Scheme 1. Synthesis of \{[2,3-Di/mono substituted-4-(1H-imidazol-2yl)carbonyl]-phenoxy\}acetic/butyric acids. 
<smiles>[R2]c1c(O)ccc(C(O)c2nccn2[3H])c1[R]</smiles>

3a-c

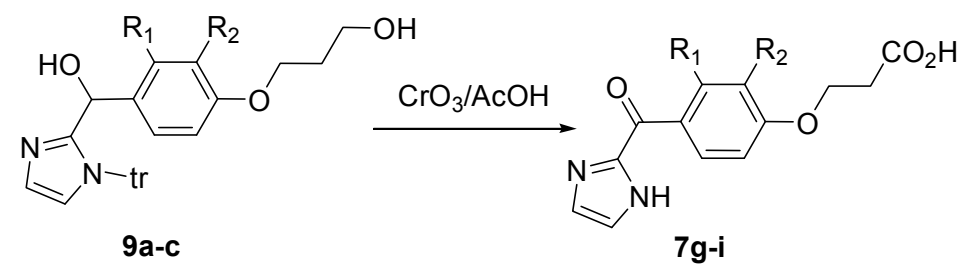

$$
\begin{aligned}
& \text { 9a: } R^{1}=R^{2}=C l \\
& \text { 9b: } R^{1}=H, R^{2}=C l \\
& \text { 9c: } R^{1}=C l, R^{2}=H
\end{aligned}
$$

$7 \mathrm{R} \mathrm{R}^{1}=\mathrm{R}^{2}=\mathrm{Cl}$

7h: $\mathrm{R}^{1}=\mathrm{H}, \mathrm{R}^{2}=\mathrm{Cl}$

7i: $\mathrm{R}^{1}=\mathrm{Cl}, \mathrm{R}^{2}=\mathrm{H}$

Scheme 2. Synthesis of $\{[2,3-\mathrm{Di} /$ mono substituted-4-(1H-imidazol-2yl)carbonyl $]$-phenoxy $\}$ propionic acids.

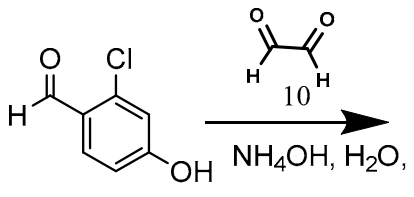

$1 \mathrm{c}$<smiles>CCOC(=O)C[C@H]1C[C@H]2CC[C@H]1CC2</smiles>

11<smiles>CCOCOc1ccc(-c2ncc[nH]2)c(Cl)c1</smiles>

12

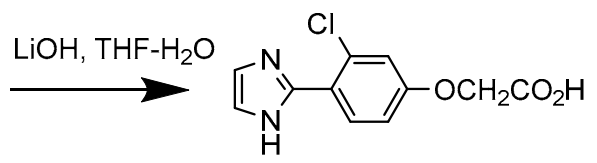

13

Scheme 3. Synthesis of 2-[3-chloro-4-(1H-imidazol-2-yl)phenoxy]acetic acid.

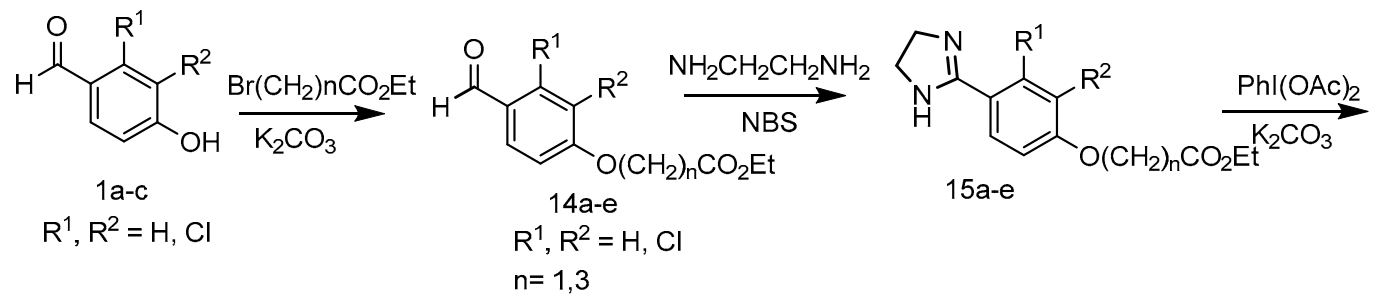

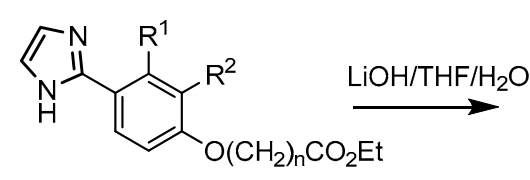

16a-e<smiles>[R]c1c(OCCC(=O)O)ccc(-c2ncc[nH]2)c1[R]</smiles>

17a-e
a: $\mathrm{R}^{1}, \mathrm{R}^{2}=\mathrm{Cl}, \mathrm{n}=1$
$b: R^{1}=H R^{2}=C l n=1$
c: $\mathrm{R}^{1}=\mathrm{Cl}, \mathrm{R}^{2}=\mathrm{Cl} \mathrm{n}=3$
$\mathrm{d}: \mathrm{R}^{1}=\mathrm{H}, \mathrm{R}^{2}=\mathrm{Cl}, \mathrm{n}=3$
e: $\mathrm{R}^{1}=\mathrm{Cl}, \mathrm{R}^{2}=\mathrm{H} n=3$

Scheme 4. Synthesis of 2-[Di/monochloro-4-(1H-imidazol-2-yl)phenoxy]acetic/butyric acids. 


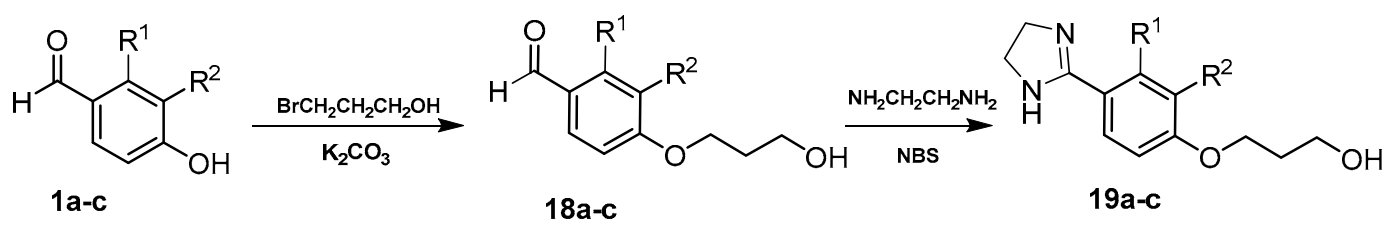

$\mathrm{R}_{1}, \mathrm{R}_{2}=\mathrm{H}, \mathrm{Cl}$

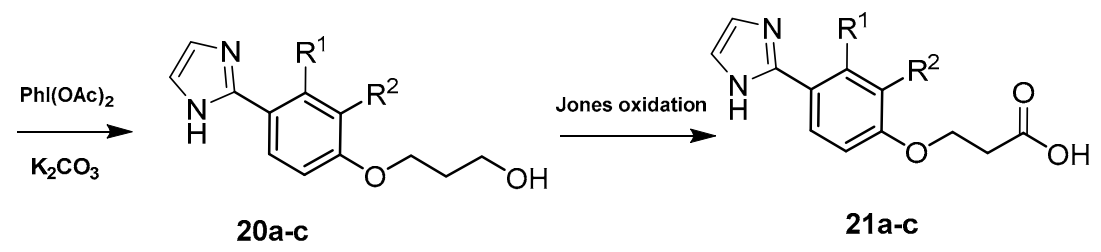
a: $\mathrm{R}^{1}, \mathrm{R}^{2}=\mathrm{Cl}$
$b: R^{1}=H, R^{2}=C l$
C: $\mathrm{R}^{1}=\mathrm{Cl}, \mathrm{R}^{2}=\mathrm{H}$

Scheme 5. Synthesis of 2-[Di/monochloro-4-(1H-imidazol-2-yl)phenoxy]propionic acids.

\subsection{Test Compounds Showed no Antisickling Effect}

The KAUS compounds were expected to bind to the $\alpha \operatorname{Trp} 14$ site and prevent sickling of red blood cells through polymer destabilization. We therefore tested selected compounds, including KAUS-4, KAUS-23 and KAUS-24, and the control clofibrate $(2 \mathrm{mM})$ on their effect on sickle RBC morphology as previously reported $[18,19,22]$. Unexpectedly, the antisickling study showed KAUS-4 to have almost no effect on the RBC morphology, while both KAUS-23 and KAUS-24 actually induced sickling (Figure 3).

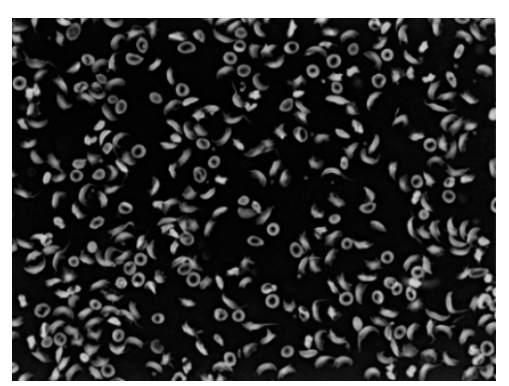

Control (buffer)

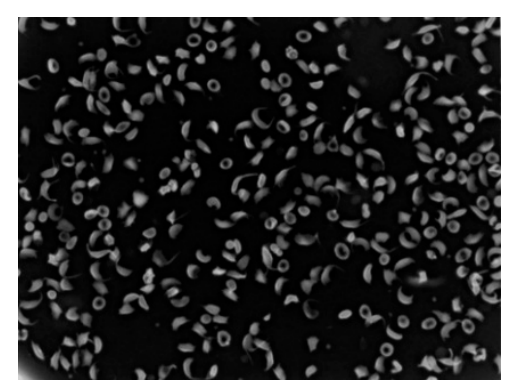

KAUS-4

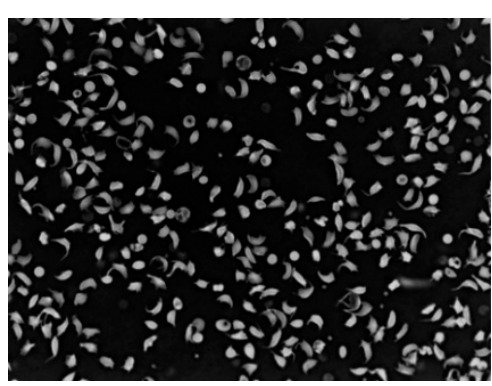

KAUS-24

Figure 3. RBC morphological antisickling results of compounds KAUS-4 and KAUS-24. Note that clofibrate and KAUS-23 showed similar prosickling effect as KAUS-24.

Clofibrate acted similarly to KAUS-23 and KAUS-24. It is apparent that our structural modifications failed to have the desired biological effect. Based on this result we speculated that the KAUS compounds instead of binding to the $\alpha \operatorname{Trp} 14$ site, are probably binding to the central water cavity of the protein to decrease the protein affinity for oxygen, resulting in the observed biological activities. We therefore undertook both oxygen equilibrium curve and crystallographic studies to understand the biological behavior of the compounds.

\subsection{Compounds Either Showed no Allosteric Activity or Produced Low-Affinity Hemoglobin}

All the KAUS compounds, as well as clofibrate, were studied at $2 \mathrm{mM}$ concentration to determine their effect on $\mathrm{Hb}$ oxygen binding property using normal whole blood following published procedures $[18,19,22]$. The results are shown in Tables 1 and 2. 
Table 1. The Effect of Compounds 7a-i on $\mathrm{Hb}$ Affinity for Oxygen Using Normal Whole Blood ${ }^{\mathrm{a}}$.

\begin{tabular}{|c|c|c|c|c|c|c|}
\hline Comp. & Name & $\mathbf{R}_{\mathbf{1}}$ & $\mathbf{R}_{\mathbf{2}}$ & $\mathbf{N}$ & Mean $P_{50} b$ & $\Delta \mathbf{P}_{50}{ }^{c}$ \\
\hline Ctr & $\mathrm{DMSO}^{\mathrm{d}}$ & & & & $38.3 \pm 0.0$ & 0.0 \\
\hline Ctr & Clofibrate & & & & $40.3 \pm 0.1$ & $2.0 \pm 0.1$ \\
\hline $7 a$ & KAUS-1 & $\mathrm{Cl}$ & $\mathrm{Cl}$ & 1 & $38.3 \pm 0.4$ & $0.0 \pm 0.4$ \\
\hline $7 \mathrm{~b}$ & KAUS-4 & $\mathrm{H}$ & $\mathrm{Cl}$ & 1 & $37.5 \pm 0.3$ & $-0.8 \pm 0.3$ \\
\hline $7 c$ & KAUS-7 & $\mathrm{Cl}$ & $\mathrm{H}$ & 1 & $39.3 \pm 0.6$ & $1.0 \pm 0.6$ \\
\hline $7 d$ & KAUS-3 & $\mathrm{Cl}$ & $\mathrm{Cl}$ & 3 & $38.6 \pm 0.1$ & $0.3 \pm 0.1$ \\
\hline $7 e$ & KAUS-6 & $\mathrm{H}$ & $\mathrm{Cl}$ & 3 & $38.6 \pm 0.6$ & $0.3 \pm 0.6$ \\
\hline $7 f$ & KAUS-9 & $\mathrm{Cl}$ & $\mathrm{H}$ & 3 & $38.2 \pm 0.5$ & $-0.1 \pm 0.5$ \\
\hline $7 g$ & KAUS-2 & $\mathrm{Cl}$ & $\mathrm{Cl}$ & 2 & $38.6 \pm 0.1$ & $0.3 \pm 0.1$ \\
\hline $7 \mathrm{~h}$ & KAUS-5 & $\mathrm{H}$ & $\mathrm{Cl}$ & 2 & $39.2 \pm 0.4$ & $0.9 \pm 0.4$ \\
\hline $7 \mathrm{i}$ & KAUS-8 & $\mathrm{Cl}$ & $\mathrm{H}$ & 2 & $38.6 \pm 0.4$ & $0.3 \pm 0.4$ \\
\hline
\end{tabular}

${ }^{a}$ Results are the means of two or three measurements. ${ }^{b} \mathrm{P}_{50}$ is the oxygen pressure in $\mathrm{mmHg}$ at which normal RBC (22\% hematocrit) is $50 \%$ saturated with oxygen. ${ }^{c} \Delta \mathrm{P}_{50}(\mathrm{~mm} \mathrm{Hg})$ is $\mathrm{P}_{50}$ of compound treated cells $-\mathrm{P}_{50}$ of control. ${ }^{\mathrm{d}}$ The final concentration of DMSO was $<2 \%$ in all samples.

Table 2. The Effect of Compounds (13, 17a-e, 21a-c) on Hb Affinity for Oxygen Using Normal Whole Blood ${ }^{\mathrm{a}}$.

\begin{tabular}{|c|c|c|c|c|c|c|}
\hline Comp. & Name & $\mathbf{R}_{1}$ & $\mathbf{R}_{\mathbf{2}}$ & $\mathbf{N}$ & Mean $P_{50}{ }^{b}$ & $\Delta \mathbf{P}_{50}{ }^{\mathrm{c}}$ \\
\hline Ctr & $\mathrm{DMSO}^{\mathrm{d}}$ & & & & $38.3 \pm 0.0$ & 0.0 \\
\hline 13 & KAUS-25 & $\mathrm{Cl}$ & $\mathrm{H}$ & 1 & $39.7 \pm 0.3$ & $1.4 \pm 0.3$ \\
\hline $17 a$ & KAUS-19 & $\mathrm{Cl}$ & $\mathrm{Cl}$ & 1 & $39.2 \pm 0.2$ & $0.9 \pm 0.2$ \\
\hline $17 \mathrm{~b}$ & KAUS-22 & $\mathrm{H}$ & $\mathrm{Cl}$ & 1 & $41.3 \pm 0.05$ & $2.9 \pm 0.05$ \\
\hline $21 c$ & KAUS-26 & $\mathrm{Cl}$ & $\mathrm{H}$ & 2 & $39.7 \pm 0.1$ & $1.4 \pm 0.1$ \\
\hline $21 a$ & KAUS-20 & $\mathrm{Cl}$ & $\mathrm{Cl}$ & 2 & $38.9 \pm 0.3$ & $0.7 \pm 0.3$ \\
\hline $21 b$ & KAUS-23 & $\mathrm{H}$ & $\mathrm{Cl}$ & 2 & $40.8 \pm 0.02$ & $2.5 \pm 0.02$ \\
\hline $17 \mathrm{e}$ & KAUS-27 & $\mathrm{Cl}$ & $\mathrm{H}$ & 3 & $39.1 \pm 0.3$ & $0.8 \pm 0.3$ \\
\hline $17 \mathrm{c}$ & KAUS-21 & $\mathrm{Cl}$ & $\mathrm{Cl}$ & 3 & $39.6 \pm 0.6$ & $1.3 \pm 0.6$ \\
\hline $17 d$ & KAUS-24 & $\mathrm{H}$ & $\mathrm{Cl}$ & 3 & $41.7 \pm 0.3$ & $3.4 \pm 0.3$ \\
\hline
\end{tabular}

a The results are the means of two or three measurements. ${ }^{b} \mathrm{P}_{50}$ is the oxygen pressure at which normal RBC ( $22 \%$ hematocrit) is $50 \%$ saturated with oxygen. ${ }^{c} \Delta \mathrm{P}_{50}$ is $\mathrm{P}_{50}$ of compound treated cells $-\mathrm{P}_{50}$ of control.

$\mathrm{d}$ The final concentration of DMSO was $<2 \%$ in all samples.

Compounds that increase or decrease the oxygen affinity of $\mathrm{Hb}$ are expected to shift the OEC to the left or right, respectively, and the degree of shift is reported as a decrease or increase in $\mathrm{P}_{50}$ (the oxygen tension at $50 \% \mathrm{Hb} \mathrm{O}_{2}$ saturation). Clofibrate slightly decreased the protein affinity for oxygen $\left(\Delta \mathrm{P}_{50}\right.$ of $\left.2 \mathrm{mmHg}\right)$ consistent with its prosickling activity. The KAUS compounds either showed no significant effect on $\mathrm{Hb}$ allosteric activity, as observed with the (imidazole-2-carbonyl)phenoxy-alkanoic acids KAUS 1-8 (Table 1) or marginally decreased the protein affinity for oxygen as observed with the (imidazol-2-yl)phenoxyalkanoic acids KAUS 20-27 (Table 2). Among the three subclasses of the (imidazol-2-yl)phenoxyalkanoic acids (different carboxylate chain lengths), the compounds with chloro substitution at the 2-position (KAUS-22, KAUS-23 and KAUS-24) produced the most low-affinity $\mathrm{Hb}$ with $\Delta \mathrm{P}_{50}$ shift of $2.9,2.5$ and $3.4 \mathrm{mmHg}$, respectively, with no apparent correlation between the varying carboxylic arm length and the $P_{50}$ shift. It is evident that the KAUS compounds generally did not increase $\mathrm{Hb}$ oxygen affinity and thus not expected to prevent hypoxia-induced RBC sickling. It is also apparent that the compounds that produced low-affinity $\mathrm{Hb}$, e.g., KAUS-23 and KAUS-24 
are the ones that promoted sickling, while KAUS-4 which showed almost no effect on Hb oxygen binding properties virtually have no effect on RBC morphology. These observations in addition to the antisickling results confirm our suspicion that the compounds do not bind to the $\alpha \operatorname{Trp} 14$ site as predicted by our design, but most likely bind to the central water cavity. X-ray crystallographic study was then conducted to determine the actual binding site of these compounds.

\subsection{Structural Studies Showed KAUS-23 Bound Exclusively to the Central Water Cavity of Hemoglobin}

Attempts were made to co-crystallize KAUS-4, KAUS-23, and KAUS-24 with deoxygenated $\mathrm{Hb}$ using high-salt conditions as previously published [22,34].

Table 3. Data collection and refinement statistics of deoxygenated $\mathrm{Hb}$ in complex with KAUS-23. Numbers in parentheses are for the highest resolution shell.

\begin{tabular}{|c|c|}
\hline Data & KAUS-23 \\
\hline Space group & $\mathrm{P} 2_{1}$ \\
\hline Unit-cell $a, b, c(\AA)$ & $62.2,80.8,53.4,90.0,99.2,90.0$ \\
\hline Resolution (Å) & $29.64-2.15(2.23-2.15)$ \\
\hline Unique reflections & 27383 \\
\hline Redundancy & 6.75 \\
\hline Completeness (\%) & $96.2(94.1)$ \\
\hline 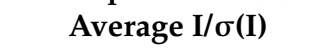 & $21.0(8.4)$ \\
\hline$R_{\text {merge }}(\%){ }^{a}$ & $6.4(14.6)$ \\
\hline \multicolumn{2}{|l|}{ Refinement $^{b}$} \\
\hline Resolution (Å) & $29.64-2.15(2.23-2.15)$ \\
\hline No. of reflections & $27358(2521)$ \\
\hline$R_{\text {work }}(\%)$ & $19.24(24.73)$ \\
\hline$R_{\text {free }}(\%)$ & $25.71(35.69)$ \\
\hline R.m.s.d. bonds $(\AA ̊)$ & 0.007 \\
\hline R.m.s.d. angles $\left({ }^{\circ}\right)$ & 1.28 \\
\hline \multicolumn{2}{|l|}{ Dihedral angles } \\
\hline Most favored (\%) & 95.6 \\
\hline Allowed (\%) & 3.7 \\
\hline \multicolumn{2}{|l|}{ Average $B\left(\AA^{2}\right)$ / atoms } \\
\hline All atoms & 29.4 \\
\hline Protein & 29.0 \\
\hline Hemes & 27.2 \\
\hline KAUS-23 & 40.7 \\
\hline Phosphate & 54.6 \\
\hline Water & 34.7 \\
\hline PDB ID code & $5 \mathrm{KDQ}$ \\
\hline
\end{tabular}

X-ray quality T-state crystals were obtained only for KAUS-23, which crystallized with a tetramer in the asymmetric unit and in space group $\mathrm{P} 22_{1}$. The crystals are isomorphous with the native deoxygenated $\mathrm{Hb}$ crystal (PDB code 2DN2) [35], necessitating the use of 2DN2 as the starting model for the refinement. Structural statistics are summarized in Table 3. The structure has been deposited in the PDB with the ID code 5KDQ.

As suspected from the OEC and antisickling results, the complex structure showed exclusive binding of KAUS-23 in the central water cavity, close to the $\alpha$-cleft with no apparent binding at the expected $\alpha \operatorname{Trp} 14$ binding site (Figure 4a). We expected two molecules of KAUS-23 to bind, however, only one of the compounds was included in the final structural model as the density at the symmetry-related site was too weak and broken to allow fitting of the second compound. Water molecules were instead modelled into the broken densities (Figure S1). 


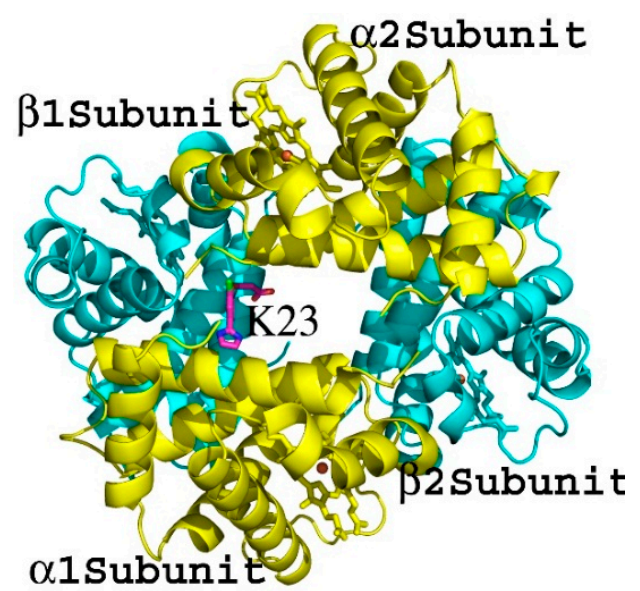

(a)

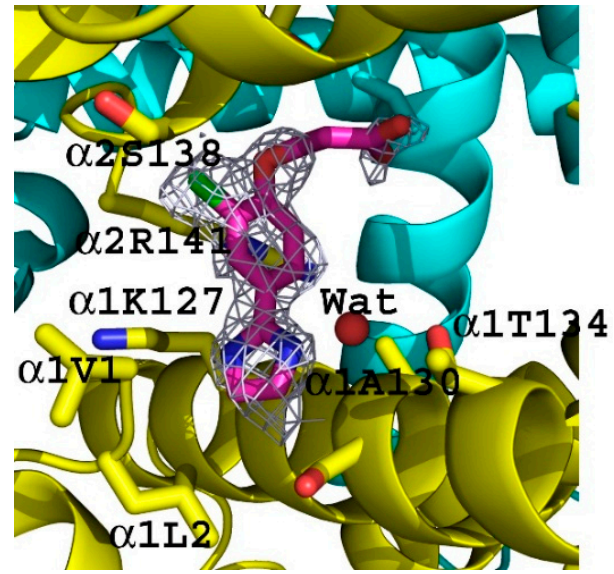

(b)

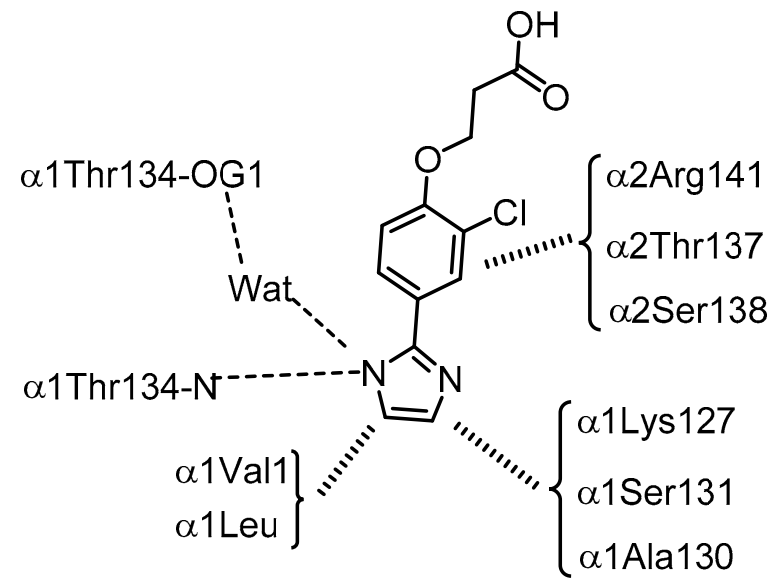

(c)

Figure 4. Tetrameric structure of deoxygenated $\mathrm{Hb}$ (ribbon) in complex with KAUS-23 (K23; sticks). (a) KAUS-23 bound in the central water cavity. Note that only one of the symmetry-related molecules was modelled since the electron density of the second site was too weak and disordered. The $\alpha$-subunits are colored in yellow and $\beta$-subunits in cyan; (b) Close-up view of KAUS-23 binding with the final $2 \mathrm{Fo}-\mathrm{Fc}$ refined electron density map contoured at $0.8 \sigma$. For clarity, not all binding site residues shown but described in the text; (c) Schematic representation of the interactions between KAUS-23 and the protein at the central water cavity.

Although the imidazole and chlorophenoxy moieties show relatively well-defined density, the carboxylate group was characterized by weak and highly disordered electron densities (Figure 4b). The imidazole moiety is located in a hydrophobic pocket formed by $\alpha 1$ Val1, $\alpha 1$ Leu2, $\alpha 1$ Lys127, $\alpha 1$ Ser131 and $\alpha 1$ Ala130 (Figure 4c). One of the nitrogen atoms of the imidazole forms a water-mediated hydrogen-bond interaction with the side chain of $\alpha 1$ Thr134, as well as a direct hydrogen-bond interaction with the main-chain nitrogen atom. Note that all these reactions involve residues from the same $\alpha$-subunit. The chlorophenoxycarboxylic acid moiety directs further down the central water cavity, where the chlorophenyl group makes inter-subunit hydrophobic interactions with $\alpha 2 \operatorname{Arg} 141$, $\alpha 2$ Thr137 and $\alpha 2$ Ser138. As noted above, the carboxylate is characterized by very weak density, consistent with the apparent lack of interaction with the protein. It is notable that the KAUS-23 binding site overlaps the chloride ion binding sites at the $\alpha$-cleft and could potentially inhibit chloride ion binding and influence the Bohr effect [36].

Interestingly, when KAUS-23 is compared to clofibrate, the two compounds bind at different sites in the central water cavity. Note that the coordinate for the deoxygenated $\mathrm{Hb}$-clofibrate structure is not available, but clofibrate binding at the central water cavity has been described in published 
articles at a site surrounded by the $\alpha$ Tyr140, $\alpha$ Pro95, $\alpha$ Va196, $\beta$ Trp37, $\beta$ Asn108 and $\alpha$ Lys99 [27]. Bezafibrate, urea derivatives of bezafibrate and RSR13 (Efaproxiral) are potent allosteric effectors that were designed based on clofibrate binding to the central water cavity $[2,6,30,31,37,38]$. Expectedly, the high-resolutions structures of these compounds in complex with $\mathrm{Hb}$ show them overlapping with clofibrate, allowing for better atomic level understanding of how clofibrate binds and stabilizes the T-state $\mathrm{Hb}$. Specifically, these effectors interact with one $\beta$-chain and two $\alpha$-chains that involve $\alpha$ His103, $\alpha$ Lys99, $\beta$ Asn108, $\beta$ Tyr35, $\beta$ Trp37 and $\alpha$ Val96; residues that are known to surround clofibrate binding. Notably, these residues are known to shift significantly during the $T \rightarrow R$ transition and their interactions with the effectors freeze them from moving to the R-state position $[1,2]$.

Like clofibrate, bezafibrate, RSR13 and several of their analogs and derivatives, the inter-molecular mediated interaction of KAUS-23 with the protein is expected to stabilize the T-state [1,2], consistent with its observed allosteric activity of decreasing the protein affinity for oxygen. We expect other KAUS compounds to bind in a similar fashion in the central water cavity, although subtle differences in their binding modes may have different stabilization effect on the T-state, explaining the differences in their allosteric properties. This is consistent with several oxygen binding and crystallographic studies that show effectors binding at the same site of $\mathrm{Hb}$ yet shift the oxygen equilibrium curve by different degrees $[1,2,39]$. We are currently working to co-crystallize $\mathrm{Hb}$ and the KAUS compounds that exhibit a wide range of activity that are likely to provide additional explanation for their properties.

\section{Experimental Section}

\subsection{Materials}

Normal whole blood was collected from adult donors at the Virginia Commonwealth University (Richmond, VA, USA) after informed consent. $\mathrm{Hb}$ was purified from discarded normal blood samples following a published procedure [34]. The use of these human samples is in accordance with regulations of the IRB for Protection of Human Subjects. For the sickling assays, leftover blood samples from patients with homozygous SS were utilized, based on an approved IRB protocol at the Children's Hospital of Philadelphia (Philadelphia, PA, USA), with informed consent.

\subsection{Chemistry}

Except as otherwise indicated, all reactions were carried out under a nitrogen atmosphere in flame- or oven-dried glassware. Reagents and solvents for chemical synthesis were purchased from Sigma-Aldrich (St. Louis, MO, USA; through Bayouni Imp. Inc., Dist., Jeddah, Saudi Arabia), Alfa Aesr (Haverhill, MA, USA; through Saggaf Co., Dist, Jeddah, Saudi Arabia) or Acros Organics (Geel, Belgium; through Abdullatif H. Abuljadayel Est., Dist, Jeddah, Saudi Arabia) as ACS-reagent grade; and used without further purification. Tetrahydrofuran (THF) was distilled from sodium/benzophenone-ketyl. Reactions were monitored by thin layer chromatography (TLC) with 0.25 -mm pre-coated silica gel plates (E. Merck, Billerica, MA, USA). ${ }^{1} \mathrm{H}-\mathrm{NMR}$ spectra were recorded on an AV-300 NMR spectrometer (Bruker Billerica, MA, USA) equipped with the Top Spin software. Infrared spectra were recorded on a Bruker ATIR spectrometer. Melting points were recorded on a Buchi (Flawil, Switzerland; Bayouni Imp. Inc.) melting point apparatus and were uncorrected. LCMS were run on an Agilent 6130 Series (Santa Clara, CA, USA), single quad instrument. HPLC separation was run on 1200 SERIES HPLC using Chemstation Software (B.02, Agilent). Purities were assessed by HPLC and were confirmed to be $>95 \%$ for all final compounds. Elemental analyses were performed using Vario, an Elementary apparatus (Shimadzu, Kyoto, Japan), located at the Organic Microanalysis Unit, Cairo University (Giza, Egypt). Column chromatography was performed on silica gel 60 (particle size $0.06-0.20 \mathrm{~mm}$ ). Jones' reagent was prepared by adding glacial acetic acid $(6 \mathrm{~mL})$ drop wise to an ice cold solution of $\mathrm{CrO}_{3}(6.7 \mathrm{~g})$ in water $(50 \mathrm{~mL})$. The orange solution was stirred for $30 \mathrm{~min}$ at the same temperature. Freshly prepared solution was used for oxidation reactions. 
3.3. General Procedure for the Synthesis of 2,3-Di/monosubstituted-4-[(1-trityl-1H-imidazol-2-yl)hydroxymethyl]phenols 3a-c [40]

To a solution of 1-tritylimidazole $(8.12 \mathrm{~g}, 26.160 \mathrm{mmol})$ in anhydrous THF $(165 \mathrm{~mL})$ was added $n$-BuLi (1.28 M in THF, $20.0 \mathrm{~mL}, 1.67 \mathrm{~g}, 13.08 \mathrm{mmol})$ at $-20{ }^{\circ} \mathrm{C}$ over a period of $20 \mathrm{~min}$ under nitrogen atmosphere. The red solution was allowed to attain room temperature and stirred for $1 \mathrm{~h}$, then cooled to $-78{ }^{\circ} \mathrm{C}$. In a separate flask the appropriate aldehyde $\mathbf{1 a}-\mathbf{c}(10.47 \mathrm{mmol})$ was dissolved in anhydrous THF $(4 \mathrm{~mL})$ and added to the red solution dropwise at $-78^{\circ} \mathrm{C}$. The reaction mixture was stirred at $-78{ }^{\circ} \mathrm{C}$ for $1 \mathrm{~h}$ and slowly brought to room temperature during which red color tuned to yellow and then to colorless. After complete reaction, saturated $\mathrm{NH}_{4} \mathrm{Cl}(250 \mathrm{~mL})$ was added to the reaction mixture at $-78{ }^{\circ} \mathrm{C}$. The resulting mixture was extracted with EtOAc $(3 \times 100 \mathrm{~mL})$; the organic layer was separated, washed with water, saturated $\mathrm{NaCl}$, and dried over anhydrous $\mathrm{Na}_{2} \mathrm{SO}_{4}$. The organic layer was evaporated in vacuo and the residue washed with cold $\mathrm{CH}_{2} \mathrm{Cl}_{2}$.

2,3-Dichloro-4-[(1-trityl-1H-imidazol-2-yl)hydroxymethyl]phenol (3a): white solid (3.99 g, 76\%), m.p. 190.0-191.8 ${ }^{\circ} \mathrm{C} .{ }^{1} \mathrm{H}-\mathrm{NMR}\left(\mathrm{DMSO}-d_{6}\right) \delta 10.42$ (s, 1H, OH), 7.25-7.21 (m, 9H, trityl-H), 7.08 $(\mathrm{d}, 2 \mathrm{H}, J=8.7 \mathrm{~Hz}, \mathrm{Ar}-\mathrm{H}), 7.00-6.98(\mathrm{~m}, 6 \mathrm{H}$, trityl-H), 6.67 (d, 2H, J = 4.8 Hz, imidazole-H), 5.25 (d, $1 \mathrm{H}$, $J=7.8 \mathrm{~Hz}, \mathrm{OH}), 5.18(\mathrm{~d}, 1 \mathrm{H}, J=7.8 \mathrm{~Hz}, \mathrm{CH})$.

2-Chloro-4-[(1-trityl-1H-imidazol-2-yl)hydroxymethyl]phenol (3b): white solid (2.76 g 93\%), m.p. 165.2-166.5 ${ }^{\circ} \mathrm{C}$. ${ }^{1} \mathrm{H}-\mathrm{NMR}\left(\mathrm{DMSO}-d_{6}\right) \delta 9.83(\mathrm{~s}, 1 \mathrm{H}, \mathrm{OH}), 7.35-7.33(\mathrm{~m}, 9 \mathrm{H}$, trityl-H), 7.09-7.07 (m, 6H, trityl-H), 6.96 (s, 1H, Ar-H3), 6.57-6.39 (m, 3H, Ar-H and imidazole-H), 6.37 (d, 1H, J = 8.7 Hz, imidazole-H), 5.38 $(\mathrm{d}, 1 \mathrm{H}, J=6.6 \mathrm{~Hz}, \mathrm{OH}), 4.82(\mathrm{~d}, 1 \mathrm{H}, J=6.3 \mathrm{~Hz}, \mathrm{CH})$.

3-Chloro-4-[(1-trityl-1H-imidazol-2-yl)hydroxymethyl]phenol (3c): white solid (2.1 g, 70.4\%), m.p. 196.0-197.7 ${ }^{\circ} \mathrm{C}$. ${ }^{1} \mathrm{H}-\mathrm{NMR}\left(\mathrm{DMSO}-d_{6}\right) \delta 9.59$ (s, 1H, OH), 7.24-7.00 (m, 10H, Ar-H and trityl-H), 6.99-6.65 (m, 6H, trityl-H), 6.64 (s, 1H, Ar-H2), 6.49-6.43 (m, 3H, Ar-H and imidazole-H), 5.23 (d, 1H, J = 6.6 Hz, $\mathrm{OH}), 4.90(\mathrm{~d}, 1 \mathrm{H}, J=6.6 \mathrm{~Hz}, \mathrm{CH})$.

3.4. General Procedure for the Synthesis of Ethyl \{2,3-Di/monosubstituted-4-[(1-trityl-1H-imidazol-2-yl)hydroxymethyl]phenoxy\}esters 5a-f [41]

To a solution of the appropriate alcohol $3(7.75 \mathrm{mmol})$ in anhydrous DMF $(45 \mathrm{~mL})$ was added $\mathrm{K}_{2} \mathrm{CO}_{3}(3.082 \mathrm{~g}, 22.300 \mathrm{mmol})$ at room temperature and stirred for $1 \mathrm{~h}$. To the reaction mixture bromo ethyl esters $4(10.70 \mathrm{mmol})$ was added and stirred for 5-6 h at room temperature. Water $(450 \mathrm{~mL}) \mathrm{was}$ added, and the precipitated solid was filtered and dried. The crude products were used as such in the next step without further purification.

Ethyl \{2,3-dichloro-4-[(1-trityl-1H-imidazol-2-yl)hydroxymethyl]phenoxy\}acetate (5a): white solid (4.82 g, 94\%), m.p. 169.1-171.5 ${ }^{\circ} \mathrm{C}$. The ${ }^{1} \mathrm{H}-\mathrm{NMR}\left(\mathrm{DMSO}-d_{6}\right) \delta$ 7.39-7.10 (9H, m, trityl-H), 6.98-6.81 (m, 7H, trityl-H and $\mathrm{Ar}-\mathrm{H}), 6.80(\mathrm{~d}, 1 \mathrm{H}, J=9 \mathrm{~Hz}, \mathrm{Ar}-\mathrm{H}), 5.56(\mathrm{~d}, 1 \mathrm{H}, J=6.9 \mathrm{~Hz}, \mathrm{OH}), 4.80(\mathrm{~d}, 1 \mathrm{H}, J=6.9 \mathrm{~Hz}, \mathrm{CH}), 4.75(\mathrm{~s}$, $\left.2 \mathrm{H}, \mathrm{OCH}_{2}\right), 4.18\left(\mathrm{q}, 2 \mathrm{H}, J=6.9 \mathrm{~Hz}, \mathrm{CH}_{2}\right), 1.24\left(\mathrm{t}, 3 \mathrm{H}, J=6.9 \mathrm{~Hz}, \mathrm{CH}_{3}\right)$.

Ethyl \{2-chloro-4-[(1-trityl-1H-imidazol-2-yl)hydroxymethyl]phenoxy\}acetate (5b): white solid (2.0 g, 88.8\%), m.p. 161.5-163.9 ${ }^{\circ} \mathrm{C} .{ }^{1} \mathrm{H}-\mathrm{NMR}\left(\mathrm{DMSO}-d_{6}\right) \delta 7.39-7.33(\mathrm{~m}, 9 \mathrm{H}$, trityl-H), 7.10-7.07 (m, 6H, trityl-H), 6.98 (s, 1H, Ar-H3), $6.66(\mathrm{~d}, 1 \mathrm{H}, J=8.7 \mathrm{~Hz}, \mathrm{Ar}-\mathrm{H} 6), 6.57-6.49(\mathrm{~m}, 3 \mathrm{H}, \mathrm{Ar}-\mathrm{H} 5$ and imidazole-H), 5.55 (s, $1 \mathrm{H}$, $\mathrm{OH}), 4.87(\mathrm{~s}, 1 \mathrm{H}, \mathrm{CH}), 4.75\left(\mathrm{~s}, 1 \mathrm{H}, \mathrm{OCH}_{2}\right), 4.16\left(\mathrm{q}, 2 \mathrm{H}, \mathrm{J}=7.1 \mathrm{~Hz}, \mathrm{CH}_{2}\right), 1.22\left(\mathrm{t}, 3 \mathrm{H}, J=6.9 \mathrm{~Hz}, \mathrm{CH}_{3}\right)$.

Ethyl \{3-chloro-4-[1-trityl-1H-imidazol-2-yl)hydroxymethyl]phenoxy\}acetate (5c): white solid (1.5 g, 84.4\%), m.p. 189.3-192.3 ${ }^{\circ} \mathrm{C} .{ }^{1} \mathrm{H}-\mathrm{NMR}\left(\mathrm{DMSO}-d_{6}\right) \delta$ 7.30-7.22 (m, 10H, Ar-H and trityl-H), 7.08 (s, 1H, Ar-H2), 7.01-6.98 (m, 6H, trityl-H), 6.68-6.63 (m, 3H, Ar-H and imidazole-H), $5.25(\mathrm{~d}, 1 \mathrm{H}, \mathrm{J}=6.9 \mathrm{~Hz}, \mathrm{OH}), 5.12$ $(\mathrm{d}, 1 \mathrm{H}, \mathrm{J}=6.9 \mathrm{~Hz}, \mathrm{CH}), 4.75\left(\mathrm{~s}, 2 \mathrm{H}, \mathrm{OCH}_{2}\right), 4.16\left(\mathrm{q}, 2 \mathrm{H}, J=7.2 \mathrm{~Hz}, \mathrm{CH}_{2}\right), 1.23\left(\mathrm{t}, 3 \mathrm{H}, J=6 \mathrm{~Hz}, \mathrm{CH}_{3}\right)$. 
Ethyl 4-\{[2,3-Dichloro-4-(1-trityl-1H-imidazol-2-yl)hydroxymethyl]phenoxy\}butyrate (5d): white solid (3.0 g, 97.7\%), m.p. $192.1-193.6{ }^{\circ} \mathrm{C} .{ }^{1} \mathrm{H}-\mathrm{NMR}$ (DMSO-d 6 ) $\delta 7.21-7.17(\mathrm{~m}, 19 \mathrm{H}$, trityl-H, Ar-H and imidazole- $\mathrm{H}), 5.8(\mathrm{~s}, 1 \mathrm{H}, \mathrm{OH}), 5.33\left(\mathrm{t}, 2 \mathrm{H}, J=9 \mathrm{~Hz}, \mathrm{OCH}_{2}\right), 4.07\left(\mathrm{~m}, 3 \mathrm{H}, \mathrm{CH}\right.$ and $\left.\mathrm{OCH}_{2}\right), 2.5(2 \mathrm{H}$, under DMSO, $\left.\mathrm{CH}_{2}\right), 1.98\left(\mathrm{t}, 2 \mathrm{H}, J=6.6 \mathrm{~Hz}, \mathrm{CH}_{2}\right), 1.17\left(\mathrm{t}, 3 \mathrm{H}, J=6.9 \mathrm{~Hz}, \mathrm{CH}_{3}\right)$.

Ethyl 4-\{2-chloro-4-[(1-trityl-1H-imidazol-2-yl)hydroxymethyl]phenoxy\}butyrate (5e): white solid (4.1 g, 66\%), m.p. 161.5-164.9 ${ }^{\circ} \mathrm{C} .{ }^{1} \mathrm{H}-\mathrm{NMR}$ (DMSO- $\left.d_{6}\right) \delta_{\mathrm{H}} 7.33-7.20(\mathrm{~m}, 9 \mathrm{H}$, trityl-H), 7.09-7.08(m, 7H, trityl-H and Ar-H), 6.97 (s, 1H, Ar-H3), $6.73(\mathrm{~d}, 1 \mathrm{H}, J=8.7 \mathrm{~Hz}, \mathrm{Ar}-\mathrm{H} 6), 6.56-6.54(\mathrm{~m}, 2 \mathrm{H}$, imidazole-H), $5.52(\mathrm{~s}, 1 \mathrm{H}$, $\mathrm{OH}), 4.86(\mathrm{~s}, 1 \mathrm{H}, \mathrm{CH}), 4.05\left(\mathrm{q}, 2 \mathrm{H}, J=6.9 \mathrm{~Hz}, \mathrm{OCH}_{2}\right), 3.97\left(\mathrm{t}, 2 \mathrm{H}, J=7.2,6.9 \mathrm{~Hz}, \mathrm{OCH}_{2}\right), 2.45(2 \mathrm{H}$ under DMSO, $\left.\mathrm{CH}_{2}\right), 1.93\left(\mathrm{t}, 2 \mathrm{H}, J=6.6 \mathrm{~Hz}, \mathrm{CH}_{2}\right), 1.17\left(\mathrm{t}, 3 \mathrm{H}, J=6.9 \mathrm{~Hz}, \mathrm{CH}_{3}\right)$.

Ethyl 4-\{3-Chloro-4-[(1-trityl-1H-imidazol-2-yl)hydroxymethyl]phenoxy\}butyrate (5f): white solid (3.7 g, 84.95\%), m.p. 147.5-148.8 ${ }^{\circ} \mathrm{C} .{ }^{1} \mathrm{H}-\mathrm{NMR}$ (DMSO- $\left.d_{6}\right) \delta_{\mathrm{H}} 7.31-7.21(\mathrm{~m}, 10 \mathrm{H}$, trityl-H and ArH), $7.08(\mathrm{~s}, 1 \mathrm{H}, \mathrm{Ar}-\mathrm{H} 2)$, 7.01-6.99 (m, 6H, trityl-H), 6.66-6.61 (m, 3H, Ar-H and imidazole-H), $5.26(\mathrm{~s}, 1 \mathrm{H}, \mathrm{OH}), 5.06(\mathrm{~s}, 1 \mathrm{H}, \mathrm{CH})$, $4.07\left(\mathrm{q}, 2 \mathrm{H}, J=7.2,6.9 \mathrm{~Hz}, \mathrm{CH}_{2}\right), 3.94\left(\mathrm{t}, 2 \mathrm{H}, J=6,5.7 \mathrm{~Hz}, \mathrm{OCH}_{2}\right), 2.46$ (under DMSO, $\left.\mathrm{CH}_{2}\right), 1.94(\mathrm{t}, 2 \mathrm{H}$, $\left.J=6.6,6.3 \mathrm{~Hz}, \mathrm{CH}_{2}\right), 1.19\left(\mathrm{t}, 3 \mathrm{H}, J=6.9 \mathrm{~Hz}, \mathrm{CH}_{3}\right)$.

\subsection{General Procedure for the Synthesis of Ethyl \{[2,3-Di/monosubstituted-4-(1-trityl-1H-imidazol-2-yl) carbonyl]phenoxy\}esters $\mathbf{6 a}-\mathbf{f}[42]$}

To a solution of alcohol $5(7.659 \mathrm{mmol})$ in acetone $(45 \mathrm{~mL})$, Jones reagent $(30.6 \mathrm{~mL})$ at $0{ }^{\circ} \mathrm{C}$, was added. The reaction mixture was allowed to attain room temperature and stirred for $7-8 \mathrm{~h}$. Then, water $(50 \mathrm{~mL})$ was added to the reaction mixture and extracted with $\mathrm{CH}_{2} \mathrm{Cl}_{2}(3 \times 100 \mathrm{~mL})$. The organic layer was separated, washed with water, followed by saturated $\mathrm{NaCl}$. After drying over anhydrous $\mathrm{Na}_{2} \mathrm{SO}_{4}$, the organic layer was evaporated in vacuo; the obtained solid was collected and dried. The crude product was used as such in the next step without further purification.

Ethyl \{[2,3-dichloro-4-(1-trityl-1H-imidazol-2-yl)carbonyl]phenoxy\}acetate (6a): pale yellow solid (2.8 g, quantitative), m.p. $116.0-120.5^{\circ} \mathrm{C} .{ }^{1} \mathrm{H}-\mathrm{NMR}\left(\mathrm{DMSO}-d_{6}\right) \delta_{\mathrm{H}} 7.62(\mathrm{~d}, 2 \mathrm{H}, J=8.7 \mathrm{~Hz}, \mathrm{Ar}-\mathrm{H}), 7.30-7.19$ $\left(\mathrm{m}, 15 \mathrm{H}\right.$, trityl-H), $6.45\left(\mathrm{~d}, 2 \mathrm{H}, J=1.2 \mathrm{~Hz}\right.$, imidazole-H), $5.07\left(\mathrm{~s}, 2 \mathrm{H}, \mathrm{OCH}_{2}\right), 4.19(\mathrm{q}, 2 \mathrm{H}, J=7.2,6.9 \mathrm{~Hz}$, $\left.\mathrm{CH}_{2}\right), 1.23\left(\mathrm{t}, 3 \mathrm{H}, J=7.2,6.9 \mathrm{~Hz}, \mathrm{CH}_{3}\right)$.

Ethyl \{[2-Chloro-4-(1-trityl-1H-imidazol-2-yl)carbonyl]phenoxy\}acetate (6b): white solid (1.1 g, quantitative), m.p. $160.3-161.6{ }^{\circ} \mathrm{C} .{ }^{1} \mathrm{H}-\mathrm{NMR}$ (DMSO- $d_{6}$ ) $\delta_{\mathrm{H}} 7.08-7.53(\mathrm{~m}, 19 \mathrm{H}$, trityl-H, Ar-H and imidazole-H), 6.46 $(\mathrm{s}, 1 \mathrm{H}, \mathrm{Ar}-\mathrm{H} 3), 5.07\left(\mathrm{~s}, 2 \mathrm{H}, \mathrm{OCH}_{2}\right), 4.20\left(\mathrm{q}, 2 \mathrm{H}, J=7.2,6.9 \mathrm{~Hz}, \mathrm{CH}_{2}\right), 1.23\left(\mathrm{t}, 3 \mathrm{H}, J=7.2,6.9 \mathrm{~Hz}, \mathrm{CH}_{3}\right)$.

Ethyl \{[3-Chloro-4-(1H-imidazol-2-yl)carbonyl]phenoxy\}acetate (6c): white solid (0.9 g, quantitative), m.p. $171.5-172.0^{\circ} \mathrm{C} .{ }^{1} \mathrm{H}-\mathrm{NMR}\left(\mathrm{DMSO}-d_{6}\right) \delta_{\mathrm{H}} 13.56(\mathrm{~s}, 1 \mathrm{H}, \mathrm{NH}), 7.74(\mathrm{~d}, 1 \mathrm{H}, J=6.9 \mathrm{~Hz}, \mathrm{Ar}-\mathrm{H} 5)$, $7.54(\mathrm{~d}, 1 \mathrm{H}, J=1.2 \mathrm{~Hz}, \mathrm{Ar}-\mathrm{H} 2), 7.22-7.01\left(\mathrm{~m}, 3 \mathrm{H}\right.$, imidazole-H and Ar-H6), $4.95\left(\mathrm{~s}, 2 \mathrm{H}, \mathrm{OCH}_{2}\right), 4.20$ $\left(\mathrm{q}, 2 \mathrm{H}, J=7.2,6.9 \mathrm{~Hz}, \mathrm{CH}_{2}\right), 1.24\left(\mathrm{t}, 3 \mathrm{H}, J=7.2,6.9 \mathrm{~Hz}, \mathrm{CH}_{3}\right)$.

Ethyl 4-\{[2,3-Dichloro-4-(1-trityl-1H-imidazol-2-yl)carbonyl]phenoxy\}butyrate (6d): pale yellow solid (1.8 g, quantitative). The crude product was used as such in the next step without further purification. ${ }^{1} \mathrm{H}-\mathrm{NMR}\left(\mathrm{DMSO}-d_{6}\right) \delta_{\mathrm{H}} 7.33-7.19(\mathrm{~m}, 19 \mathrm{H}$, trityl-H, Ar-H and imidazole-H), $4.22(\mathrm{t}, 2 \mathrm{H}, J=6.3,6 \mathrm{~Hz}$, $\left.\mathrm{OCH}_{2}\right), 4.07\left(\mathrm{q}, 2 \mathrm{H}, J=7.2,3.9 \mathrm{~Hz}, \mathrm{CH}_{2}\right), 3.55$ (under $\left.\mathrm{DMSO}, \mathrm{CH}_{2}\right), 3.05\left(\mathrm{~m}, 2 \mathrm{H}, \mathrm{CH}_{2}\right), 1.18(\mathrm{t}, 3 \mathrm{H}$, $\left.J=7.2 \mathrm{~Hz}, \mathrm{CH}_{3}\right)$.

Ethyl 4-\{[2-Chloro-4-(1-trityl-1H-imidazol-2-yl)carbonyl]phenoxy\}butyrate (6e): white solid (3.7 g, quantitative), m.p. $169.1-171.5^{\circ} \mathrm{C} .{ }^{1} \mathrm{H}-\mathrm{NMR}$ (DMSO- $\left.d_{6}\right) \delta_{\mathrm{H}} 7.30-7.19(\mathrm{~m}, 19 \mathrm{H}$, trityl-H, Ar-H and imidazole-H), 6.46 $(\mathrm{s}, 1 \mathrm{H}, \mathrm{Ar}-\mathrm{H} 3), 4.22\left(\mathrm{t}, 2 \mathrm{H}, J=6.3,6 \mathrm{~Hz}, \mathrm{OCH}_{2}\right), 4.07\left(\mathrm{q}, 2 \mathrm{H}, J=7.2,6.9 \mathrm{~Hz}, \mathrm{OCH}_{2}\right), 3.55$ (under DMSO, $\left.\mathrm{CH}_{2}\right), 2.07-2.03\left(\mathrm{~m}, 2 \mathrm{H}, \mathrm{CH}_{2}\right), 1.18\left(\mathrm{t}, 3 \mathrm{H}, J=7.2,6.9 \mathrm{~Hz}, \mathrm{CH}_{3}\right)$.

Ethyl 4-\{[3-Chloro-4-(1H-imidazol-2-yl)carbonyl]phenoxy\}butyrate (6f): white solid (1.8 g, 89.74\%), m.p. 112.1-114.0 ${ }^{\circ} \mathrm{C} .{ }^{1} \mathrm{H}-\mathrm{NMR}\left(\mathrm{DMSO}-d_{6}\right) \delta_{\mathrm{H}} 13.52(\mathrm{~s}, 1 \mathrm{H}, \mathrm{NH}), 7.75(\mathrm{~d}, 1 \mathrm{H}, J=8.4 \mathrm{~Hz}, \mathrm{Ar}-\mathrm{H} 5)$, 7.53 (s, 1H, Ar-H2), 7.22-6.99 (m, 3H, ArH6 and imidazole-H), 4.11-4.10 (m, 4H, two $\left.\mathrm{OCH}_{2}\right), 2.51$ (under DMSO, $\left.\mathrm{CH}_{2}\right), 1.99\left(\mathrm{t}, 2 \mathrm{H}, J=6.6 \mathrm{~Hz}, \mathrm{CH}_{2}\right), 1.19\left(\mathrm{t}, 3 \mathrm{H}, J=6.9 \mathrm{~Hz}, \mathrm{CH}_{3}\right)$. 
3.6. General Procedure for the Synthesis of $\{[2,3-D i / m o n o s u b s t i t u t e d-4-(1 H$-imidazol-2yl)carbonyl]-phenoxy $\}$ acetic/butyric acids (7a-f) [43]

To solution of $6(8.159 \mathrm{mmol})$ in aqueous THF $(12 \mathrm{~mL} /$ water $6 \mathrm{~mL})$ was added $\mathrm{LiOH} \cdot \mathrm{H}_{2} \mathrm{O}(0.687 \mathrm{~g}$, $16.37 \mathrm{mmol}$ ) at room temperature. The reaction mixture was stirred for $1 \mathrm{~h}$ during which the solution turned to green. The reaction was monitored with TLC. After complete reaction, the solvent was evaporated in vacuo. The crude material was then dissolved in minimum amount of water. The precipitated solid was filtered and the $\mathrm{pH}$ of the filtrate was adjusted to 6-7 using aqueous $1.5 \mathrm{~N}$ $\mathrm{HCl}$, and the obtained solid product was collected by filtration and dried. The crude material was purified by column chromatography over silica gel (230-400 mesh) using 40 to 50\% ethyl acetate in hexane as eluent to afford the desired final products $7 \mathbf{a}-\mathbf{i}$.

\{[2,3-Dichloro-4-(1H-imidazol-2-yl)carbonyl]phenoxy\}acetic acid, (7a): white solid (1.22 g, 51\%), m.p. $240.2-243^{\circ} \mathrm{C}$. IR (KBr, $\left.v_{\max } \mathrm{cm}^{-1}\right)$ : $3527(\mathrm{OH}), 3200(\mathrm{NH}), 1662(\mathrm{CO}), 1269,1077(\mathrm{C}-\mathrm{O}-\mathrm{C}) ;{ }^{1} \mathrm{H}-\mathrm{NMR}$ $\left(\mathrm{DMSO}_{-} \mathrm{d}_{6}\right) \delta_{\mathrm{H}} 13.64(\mathrm{~s}, 1 \mathrm{H}, \mathrm{NH}), 7.64-7.57(\mathrm{~m}, 2 \mathrm{H}, \mathrm{Ar}-\mathrm{H}), 7.22-7.13(\mathrm{~m}, 2 \mathrm{H}$, imidazole-H), $4.95(\mathrm{~s}, 2 \mathrm{H}$, $\left.\mathrm{OCH}_{2}\right) ; \mathrm{LC} / \mathrm{MS}(\mathrm{ESI}) \mathrm{m} / z 315(\mathrm{M}+1), 316(\mathrm{M}+2), 317(\mathrm{M}+3), 318(\mathrm{M}+4)$.

\{[2-Chloro-4-(1H-imidazol-2-yl)carbonyl]phenoxy\}acetic acid (7b): pale yellow solid (1.04 g, 81.7\%), m.p. 303-306 ${ }^{\circ} \mathrm{C} .{ }^{1} \mathrm{H}-\mathrm{NMR}\left(\mathrm{DMSO}-d_{6}\right) \delta_{\mathrm{H}} 13.42$ (brs, 1H, NH), 8.76 (d, 1H, J = 1.8 Hz, Ar-H3), 8.39 $(\mathrm{t}, 1 \mathrm{H}, \mathrm{J}=9,1.8 \mathrm{~Hz}, \mathrm{Ar}-\mathrm{H} 5), 7.38$ (s, 2H, imidazole-H), 6.97 (d, 1H, J = 9 Hz, Ar-H6), 4.38 (s, 2H, OCH $\mathrm{O}_{2}$; LC/MS (ESI) $m / z 280.1(\mathrm{M}+), 282.1(\mathrm{M}+2)$.

\{3-Chloro-4-[(1H-imidazol-2-yl)carbonyl]phenoxy\}acetic acid (7c): white solid (0.64 g, 64.0\%), m.p. 230.8-233.9 ${ }^{\circ} \mathrm{C}$. IR (KBr, $\left.v_{\max } \mathrm{cm}^{-1}\right)$ : $3497(\mathrm{NH}), 3306(\mathrm{OH}), 1647$ (CO), 1269, 1085 (C-O-C); ${ }^{1} \mathrm{H}-\mathrm{NMR}\left(\mathrm{DMSO}-d_{6}\right) \delta_{\mathrm{H}} 13.56(\mathrm{~s}, 1 \mathrm{H}, \mathrm{NH}), 7.72(\mathrm{~d}, 1 \mathrm{H}, \mathrm{J}=8.7 \mathrm{~Hz}, \mathrm{Ar}-\mathrm{H} 5), 7.51$ (s, 1H, imidazole-H), 7.20 (s, 1H, imidazole-H), $6.96(\mathrm{~d}, 1 \mathrm{H}, \mathrm{J}=2.1 \mathrm{~Hz}, \mathrm{Ar}-\mathrm{H} 2), 6.88$ (t, 1H, J = 6.3, $2.4 \mathrm{~Hz}$ Ar-H6), 4.40 (s, 2H, $\left.\mathrm{OCH}_{2}\right) ; \mathrm{LC} / \mathrm{MS}(\mathrm{ESI}) \mathrm{m} / \mathrm{z} 280.1(\mathrm{M}+)^{-}, 282.1(\mathrm{M}+2)^{-}$.

4-\{2,3-Dichloro-4-[(1H-imidazol-2-yl)carbonyl]phenoxy\}butyric acid (7d): white solid (1.15 g, 69\%), m.p. 167.5-169.4 ${ }^{\circ} \mathrm{C}$. IR (KBr, $\left.v_{\max } \mathrm{cm}^{-1}\right)$ : 3527 (NH), $3247(\mathrm{OH}), 1643$ (CO), 1274, 1041 (C-O-C). ${ }^{1} \mathrm{H}-\mathrm{NMR}\left(\mathrm{DMSO}-d_{6}\right) \delta_{\mathrm{H}} 13.61(\mathrm{~s}, 1 \mathrm{H}, \mathrm{NH}), 7.64(\mathrm{~d}, 1 \mathrm{H}, \mathrm{J}=8.4 \mathrm{~Hz}, \mathrm{Ar}-\mathrm{H} 5), 7.36$ (s, 2H, imidazole-H), $7.29(\mathrm{~d}, 1 \mathrm{H}, \mathrm{J}=8.7 \mathrm{~Hz}, \mathrm{Ar}-\mathrm{H} 6), 4.19\left(\mathrm{t}, 2 \mathrm{H}, \mathrm{J}=6.6 \mathrm{~Hz}, \mathrm{OCH}_{2}\right), 2.13\left(\mathrm{t}, 2 \mathrm{H}, J=6.6 \mathrm{~Hz}, \mathrm{OCH}_{2}\right), 1.94(\mathrm{q}, 2 \mathrm{H}$, $\left.J=6.6,6.3 \mathrm{~Hz}, \mathrm{CH}_{2}\right)$. LC/MS (ESI) $m / z 341(\mathrm{M}-1)^{-}, 343(\mathrm{M}+1)^{-}, 344(\mathrm{M}+2)^{-}, 346(\mathrm{M}+4)^{-}$.

4-\{2-Chloro-4-[(1H-imidazol-2-yl)carbonyl]phenoxy\}butyric acid (7e): white solid (2.4 g, 71\%), m.p. 169.1-171.5 ${ }^{\circ} \mathrm{C} .{ }^{1} \mathrm{H}-\mathrm{NMR}\left(\mathrm{DMSO}-d_{6}\right) \delta_{\mathrm{H}} 13.52$ (brs, 1H, NH), 8.73 (s, 1H, Ar-H3), 8.52 (d, 1H, $J=7.8 \mathrm{~Hz}, \mathrm{Ar}-\mathrm{H} 5), 7.41-7.32\left(\mathrm{~m}, 3 \mathrm{H}, \mathrm{Ar}-\mathrm{H} 6\right.$ and imidazole-H), $4.20\left(\mathrm{t}, 2 \mathrm{H}, J=6 \mathrm{~Hz}, \mathrm{OCH}_{2}\right), 2.3(\mathrm{t}, 2 \mathrm{H}$, $\left.J=6 \mathrm{~Hz}, \mathrm{CH}_{2}\right), 1.99-1.97\left(\mathrm{~m}, 2 \mathrm{H}, \mathrm{CH}_{2}\right)$. LC/MS (ESI) $m / z 307.1(\mathrm{M}-1)^{-}, 308(\mathrm{M}+)^{-}, 309.1(\mathrm{M}+1)^{-}$, $310(\mathrm{M}+2)^{-}, 312(\mathrm{M}+4)^{-}$.

4-\{3-Chloro-4-[(1H-imidazole-2-yl)carbonyl]phenoxy\}butyric acid (7f): white solid (0.8 g, 48.5\%), m.p. 188.4-191.1 ${ }^{\circ} \mathrm{C} .{ }^{1} \mathrm{H}-\mathrm{NMR}\left(\mathrm{DMSO}-\mathrm{d}_{6}\right) \delta_{\mathrm{H}} 13.53(\mathrm{~s}, 1 \mathrm{H}, \mathrm{NH}), 12.19(\mathrm{~s}, 1 \mathrm{H}, \mathrm{OH}), 7.76(\mathrm{~d}, 1 \mathrm{H}, J=8.7 \mathrm{~Hz}$, Ar-H5), 7.52 (s, 1H, Ar-H2), 7.23 (s, 1H, imidazole-H), 7.13(s, 1H, imidazole-H), 7.02 (d, 1H, J = 8.4 Hz, Ar-H6), $4.10\left(\mathrm{t}, 2 \mathrm{H}, \mathrm{J}=6.3,6 \mathrm{~Hz}, \mathrm{OCH}_{2}\right), 2.40\left(2 \mathrm{H}\right.$, under DMSO, $\left.\mathrm{CH}_{2}\right), 1.97\left(\mathrm{~m}, 2 \mathrm{H}, \mathrm{CH}_{2}\right)$; LC/MS (ESI) $m / z 307(\mathrm{M}-1)^{-}, 309.1(\mathrm{M}+1)^{-}, 310.1(\mathrm{M}+2)^{-}, 312(\mathrm{M}+4)^{-}$.

\subsection{General Procedure for the Synthesis of 3-\{2,3-Di/monochloro-4-[(1-trityl-1H-imidazol-2-yl)hydroxy-} methyl]phenoxy\}propanols 9a-c [41]

To a solution of the appropriate alcohol $3 \mathbf{a}-\mathbf{c}(12.76 \mathrm{mmol})$ in anhydrous DMF $(65 \mathrm{~mL})$ was added $\mathrm{K}_{2} \mathrm{CO}_{3}(4.4 \mathrm{~g}, 31.84 \mathrm{mmol})$ at room temperature and stirred for $1 \mathrm{~h}$. To the reaction mixture, 3-bromopropanol (2.12 g, $1.4 \mathrm{~mL}, 15.31 \mathrm{mmol})$ was added and stirred for $16 \mathrm{~h}$ at room temperature. The solid formed after addition of water $(650 \mathrm{~mL})$ was filtered, treated with diethyl ether and dried in vacuo. 
3-\{2,3-Dichloro-4-[(1-trityl-1H-imidazol-2-yl)hydroxymethyl]phenoxy\}propanol (9a): white solid (6.34 g, 88.78\%), m.p. $\quad 174.7-177.7{ }^{\circ} \mathrm{C} .{ }^{1} \mathrm{H}-\mathrm{NMR}\left(\mathrm{DMSO}-d_{6}\right) \delta_{\mathrm{H}} 7.25-7.10(\mathrm{~m}, 11 \mathrm{H}$, trityl-H and Ar-H), 7.0-6.9 $(\mathrm{m}, 7 \mathrm{H}$, trityl-H and imidazole- $\mathrm{H}), 6.87(\mathrm{~d}, 1 \mathrm{H}, \mathrm{J}=8.4 \mathrm{~Hz}$, imidazole- $\mathrm{H}), 5.29(\mathrm{~s}, 2 \mathrm{H}, \mathrm{OH}$ and $\mathrm{CH})$, $4.6(\mathrm{brs}, 1 \mathrm{H}, \mathrm{OH}), 4.09\left(\mathrm{t}, 2 \mathrm{H}, J=6,6.3 \mathrm{~Hz}, \mathrm{OCH}_{2}\right), 3.57\left(\mathrm{t}, 2 \mathrm{H}, J=6,6.3 \mathrm{~Hz}, \mathrm{OCH}_{2}\right), 1.83$ (quint, $2 \mathrm{H}$, $J=6.3 \mathrm{~Hz}, \mathrm{CH}_{2}$ ).

3-\{2-Chloro-4-[(1-trityl-1H-imidazol-2-yl)hydroxymethyl]phenoxy\}propanol (9b): white solid (3.9 g, 88.94\%), m.p. 155.9-157.5 ${ }^{\circ} \mathrm{C} .{ }^{1} \mathrm{H}-\mathrm{NMR}$ (DMSO- $\left.d_{6}\right) \delta_{\mathrm{H}} 7.34-7.33(\mathrm{~m}, 9 \mathrm{H}$, trityl-H), 7.10-7.08 $(\mathrm{m}, 6 \mathrm{H}$, trityl-H), $6.97(\mathrm{~s}, 1 \mathrm{H}, \mathrm{Ar}-\mathrm{H} 3), 6.74(\mathrm{~d}, 1 \mathrm{H}, J=8.4 \mathrm{~Hz}, \mathrm{Ar}-\mathrm{H} 6), 6.57-6.51(\mathrm{~m}, 3 \mathrm{H}, \mathrm{ArH}$ and imidazole-H), 5.57 (brs, $1 \mathrm{H}, \mathrm{OH}), 4.86(\mathrm{~s}, 1 \mathrm{H}, \mathrm{CH}), 4.59(\mathrm{brs}, 1 \mathrm{H}, \mathrm{OH}), 4.01\left(\mathrm{t}, 2 \mathrm{H}, J=6,6.3 \mathrm{~Hz}, \mathrm{OCH}_{2}\right), 3.54(\mathrm{t}, 2 \mathrm{H}, J=6,6.3 \mathrm{~Hz}$, $\mathrm{OCH}_{2}$ ), 1.83 (quint, $2 \mathrm{H}, J=6.3 \mathrm{~Hz}, \mathrm{CH}_{2}$ ).

3-\{3-Chloro-4-[(1-trityl-1H-imidazol-2-yl)hydroxymethyl]phenoxy\}propanol (9c): white solid (4.5 g, 87.0\%), m.p. $182.3-183.9^{\circ} \mathrm{C} .{ }^{1} \mathrm{H}-\mathrm{NMR}$ (DMSO- $\left.d_{6}\right) \delta_{\mathrm{H}} 7.31-7.28(\mathrm{~m}, 10 \mathrm{H}, \mathrm{Ar}-\mathrm{H}$ and trityl-H), $7.22(\mathrm{~s}, 1 \mathrm{H}, \mathrm{Ar}-\mathrm{H} 2)$, 7.08-7.00 (m, 6H, trityl-H), 6.66-6.60 (m, 3H, ArH and imidazole-H), $5.26(\mathrm{~s}, 1 \mathrm{H}, \mathrm{CH}), 5.04$ (brs, $1 \mathrm{H}$, $\mathrm{OH}$ ), $4.56(\mathrm{brs}, 1 \mathrm{H}, \mathrm{OH}), 3.97\left(\mathrm{t}, 2 \mathrm{H}, J=6,5.4 \mathrm{~Hz}, \mathrm{OCH}_{2}\right), 3.49\left(\mathrm{t}, 2 \mathrm{H}, J=6,6.3 \mathrm{~Hz}, \mathrm{OCH}_{2}\right), 1.81$ (quint, $2 \mathrm{H}, J=6,5.7 \mathrm{~Hz}, \mathrm{CH}_{2}$ ).

3.8. General Procedure for the Synthesis of 3-\{2,3-Di/monochloro-4-[(1H-imidazol-2-yl)carbonyl]phenoxy\}propionic Acids $\mathbf{7 g}-\mathbf{i}$ [42]

To a solution of alcohol $\mathbf{9 a}-\mathbf{c}(10.72 \mathrm{mmol})$ in acetone $(60 \mathrm{~mL})$, Jones reagent $(25 \mathrm{~mL})$ was added at $0{ }^{\circ} \mathrm{C}$. The reaction mixture was allowed to attain room temperature and stirred for $48 \mathrm{~h}$ and filtered to remove insoluble impurities. The filtrate was extracted with diethyl ether $(6 \times 50 \mathrm{~mL})$. The organic layer was separated, dried over anhydrous $\mathrm{Na}_{2} \mathrm{SO}_{4}$ and evaporated in vacuo to get a pale yellow solid. The product was dissolved in $5 \% \mathrm{NaHCO}_{3}$ solution (minimum amount) and washed with diethyl ether $(2 \times 50 \mathrm{~mL})$ followed by ethyl acetate $(2 \times 50 \mathrm{~mL})$. The $\mathrm{pH}$ of the aqueous layer was carefully adjusted to 6 using $1.5 \mathrm{~N}$ aqueous $\mathrm{HCl}$. The solid product formed was filtered, washed with diethyl ether and dried.

3-\{2,3-dichloro-4-[(1H-imidazol-2-yl)carbonyl]phenoxy\}propionic acid, 7g: white solid (0.45 g, 12.75\%), m.p. $207^{\circ} \mathrm{C}$ (decomposed). IR (KBr, $\left.v_{\max } \mathrm{cm}^{-1}\right)$ : 3497(NH), $3306(\mathrm{OH}), 1647(\mathrm{CO}), 1600,1409\left(\mathrm{CO}_{2}{ }^{-}\right)$, 1270, 1035 (C-O-C). ${ }^{1} \mathrm{H}-\mathrm{NMR}\left(\mathrm{DMSO}_{6}\right) \delta 13.64(\mathrm{~s}, 1 \mathrm{H}, \mathrm{NH}), 7.67(\mathrm{~d}, 1 \mathrm{H}, J=8.7 \mathrm{~Hz}, \mathrm{Ar}-\mathrm{H} 5)$, $7.40\left(\mathrm{~s}, 2 \mathrm{H}\right.$, imidazole-H), $7.28(\mathrm{~d}, 1 \mathrm{H}, J=8.7 \mathrm{~Hz}, \mathrm{Ar}-\mathrm{H} 6), 4.36\left(\mathrm{t}, 2 \mathrm{H}, J=6 \mathrm{~Hz}, \mathrm{OCH}_{2}\right), 2.68(2 \mathrm{H}$, $\left.J=6.3,5.7 \mathrm{~Hz}, \mathrm{CH}_{2}\right)$.

3-\{2-Chloro-4-[(1H-imidazol-2-yl)carbonyl]phenoxy\}propionic acid (7h): white solid (1.0 g, 24.08\%), m.p. 195.0-195.4 ${ }^{\circ} \mathrm{C}$. IR (KBr, $\left.v_{\max } \mathrm{cm}^{-1}\right)$ : $3294(\mathrm{NH}), 3000-2800(\mathrm{OH}), 1703$ (CO), 1613(CO), 1583 $(\mathrm{C}=\mathrm{N}), 1254,1037(\mathrm{C}-\mathrm{O}-\mathrm{C}) .{ }^{1} \mathrm{H}-\mathrm{NMR}\left(\mathrm{DMSO}-d_{6}\right) \delta_{\mathrm{H}} 13.47(\mathrm{~s}, 1 \mathrm{H}, \mathrm{NH}), 12.49(\mathrm{~s}, 1 \mathrm{H}, \mathrm{OH}), 8.72(\mathrm{~d}, 1 \mathrm{H}$, $J=1.8 \mathrm{~Hz}, \mathrm{Ar}-\mathrm{H} 3), 8.53(\mathrm{t}, 1 \mathrm{H}, J=6.6,2.1 \mathrm{~Hz}, \mathrm{Ar}-\mathrm{H} 5), 7.52(\mathrm{~s}, 1 \mathrm{H}$, imidazole-H), 7.35(d, $1 \mathrm{H}, J=8.7 \mathrm{~Hz}$, Ar-H6), $7.31\left(\mathrm{~s}, 1 \mathrm{H}\right.$, imidazole-H), $4.38\left(\mathrm{t}, 2 \mathrm{H}, J=6,5.7 \mathrm{~Hz}, \mathrm{OCH}_{2}\right), 2.78\left(\mathrm{t}, 2 \mathrm{H}, J=6,5.7 \mathrm{~Hz}, \mathrm{CH}_{2}\right)$. LC/MS (ESI) $m / z 293(\mathrm{M}-1), 295(\mathrm{M}+1), 296(\mathrm{M}+2)$.

3-\{3-Chloro-4-(1H-imidazol-2-yl)carbonyl]phenoxy\}propionic acid (7i): white solid (0.536 g, 21.22\%), m.p. 193.0-194.2 ${ }^{\circ} \mathrm{C}$. IR (KBr, $v_{\max } \mathrm{cm}^{-1}$ ): $3301(\mathrm{NH}), 3100-2600(\mathrm{OH}), 1717$ (CO), 1645 (CO), 1598 $(\mathrm{C}=\mathrm{N}), 1294,1033(\mathrm{C}-\mathrm{O}-\mathrm{C}) .{ }^{1} \mathrm{H}-\mathrm{NMR}\left(\mathrm{DMSO}-d_{6}\right) \delta_{\mathrm{H}} 13.53(\mathrm{~s}, 1 \mathrm{H}, \mathrm{NH}), 12.43(\mathrm{~s}, 1 \mathrm{H}, \mathrm{OH}), 7.75(\mathrm{~d}, 1 \mathrm{H}$, $J=8.7 \mathrm{~Hz}, \mathrm{Ar}-\mathrm{H} 5), 7.53(\mathrm{~s}, 1 \mathrm{H}$, imidazole-H), $7.22(\mathrm{~s}, 1 \mathrm{H}$, imidazole-H) $7.14(\mathrm{~d}, 1 \mathrm{H}, J=2.1 \mathrm{~Hz}, \mathrm{Ar}-\mathrm{H} 2)$, $7.02(\mathrm{dd}, 1 \mathrm{H}, J=6.3,2.4 \mathrm{~Hz}, \mathrm{Ar}-\mathrm{H} 6), 4.28\left(\mathrm{t}, 2 \mathrm{H}, \mathrm{J}=6,5.7 \mathrm{~Hz}, \mathrm{OCH}_{2}\right), 2.73\left(\mathrm{t}, 2 \mathrm{H}, J=6,5.7 \mathrm{~Hz}, \mathrm{CH}_{2}\right)$. LC/MS (ESI) $m / z 293(\mathrm{M}-1), 294(\mathrm{M}+), 295(\mathrm{M}+1), 296(\mathrm{M}+2)$.

\subsection{3-Chloro-4-(1H-imidazol-2-yl)phenol (11) [30]}

Glyoxal 10 ( $40 \%$ in $\left.\mathrm{H}_{2} \mathrm{O}, 14 \mathrm{~mL}, 0.095 \mathrm{~mol}\right)$ was placed in water $(20 \mathrm{~mL})$, then added to a cooled solution (about $\left.5{ }^{\circ} \mathrm{C}\right)$ of 2-chloro-4-hydroxybenzaldehyde $1 \mathrm{c}(5 \mathrm{~g}, 0.031 \mathrm{mmol})$ in methanol $(10 \mathrm{~mL})$ to afford a white turbid solution. Ammonium hydroxide $\left(25 \%\right.$ in $\left.\mathrm{H}_{2} \mathrm{O}, 67 \mathrm{~mL}, 0.478 \mathrm{mmol}\right)$ was 
added drop wise over a period of $1 \mathrm{~h}$ at $0-5{ }^{\circ} \mathrm{C}$ and the reaction mixture was stirred for $3 \mathrm{~h}$ at $0-5{ }^{\circ} \mathrm{C}$. The mixture was allowed to warm to room temperature and stirred further for $24 \mathrm{~h}$. The solution was concentrated in vacuo and the crude was purified by column chromatography using mixture of $\mathrm{DCM} / \mathrm{MeOH}(95: 5)$ as an eluent to obtain 11 as a beige solid (6.4 g, quantitative), m.p. $155-158^{\circ} \mathrm{C}$. ${ }^{1} \mathrm{H}-\mathrm{NMR}\left(300 \mathrm{MHz}, \mathrm{DMSO}-d_{6}\right) \delta_{\mathrm{H}} 12.07$ (brs, 1H, NH), 10.20 (brs, 1H, OH), 7.52-7.63 (m, 1H, Ar-H6), 7.10 (s, 1H, Ar-H2), 6.91 (s, 2H, imidazole-H), 6.83 (d, J = 8.50 Hz, 1H, Ar-H5).

\subsection{Ethyl 2-[3-Chloro-4-(1H-imidazol-2-yl)phenoxy]acetate (12) [42]}

To a cold $\left(5-10^{\circ} \mathrm{C}\right)$ solution of $\mathbf{1 1}(9.0 \mathrm{~g}, 0.049 \mathrm{~mol})$ and $\mathrm{K}_{2} \mathrm{CO}_{3}(1 \mathrm{~g}, 0.070 \mathrm{~mol})$, KI $(0.37 \mathrm{~g}, 0.005 \mathrm{~mol})$ in DMF (90 mL), was added ethyl bromoacetate $(7 \mathrm{~g}, 0.049 \mathrm{~mol})$ while stirring. The stirring was continued for $1 \mathrm{~h}$ at room temperature. Then the reaction was treated with water $(150 \mathrm{~mL})$ and extracted in DCM $(2 \times 100 \mathrm{~mL})$. The combined organic layer was washed with water and brine, dried with anhydrous $\mathrm{Na}_{2} \mathrm{SO}_{4}$, and evaporated under vacuum to give the crude product. Purification was carried out using flash chromatography (hexane-EtOAC 3:7) to furnish a white solid of 12 (1.4 g, 11\%), m.p. $131-133{ }^{\circ} \mathrm{C} .{ }^{1} \mathrm{H}-\mathrm{NMR}\left(300 \mathrm{MHz}, \mathrm{DMSO}-d_{6}\right) \delta_{\mathrm{H}} \mathrm{ppm} 12.29$ (brs, $\left.1 \mathrm{H}, \mathrm{NH}\right) 7.67$ (d, J = 8.78 Hz, $1 \mathrm{H}$, Ar-H5), 7.07-7.21 (m, 3H, Ar-H2 and imidazole-H), 7.03 (dd, J = 8.69, 2.55 Hz, 1H, Ar-H6), 4.90 (s, $2 \mathrm{H}$, $\left.\mathrm{OCH}_{2}\right), 4.19\left(\mathrm{q}, \mathrm{J}=7.08 \mathrm{~Hz}, 2 \mathrm{H}, \mathrm{CH}_{2}\right), 1.22\left(\mathrm{t}, \mathrm{J}=7.08 \mathrm{~Hz}, 3 \mathrm{H}, \mathrm{CH}_{3}\right)$.

\subsection{2-[3-Chloro-4-(1H-imidazol-2-yl)phenoxy]acetic acid (13) [43]}

To a solution of $12(1.4 \mathrm{~g}, 0.005 \mathrm{~mol})$ in THF $(5.6 \mathrm{~mL})$ and water $(2.8 \mathrm{~mL})$ was added $\mathrm{LiOH} \cdot \mathrm{H}_{2} \mathrm{O}$ $(0.36 \mathrm{~g}, 0.015 \mathrm{~mol})$ at room temperature and stirred for $30 \mathrm{~min}$ until consumption of the starting material. The reaction was treated with $1.5 \mathrm{~N} \mathrm{HCl}$ until the $\mathrm{pH}$ of the reaction mixture became 6.5 . The precipitated product was filtered and dried under vacuum as an off-white solid, $(1.15 \mathrm{~g}, 92 \%)$, m.p. 313-316 ${ }^{\circ} \mathrm{C} .{ }^{1} \mathrm{H}-\mathrm{NMR}\left(300 \mathrm{MHz}, \mathrm{DMSO}-d_{6}\right) \delta_{\mathrm{H}}$ ppm 14.75 (brs,1H, NH), 7.81 (s, 2H, imidazole-H), $7.71(\mathrm{~d}, J=8.69 \mathrm{~Hz}, 1 \mathrm{H}, \mathrm{Ar}-\mathrm{H} 5), 7.34(\mathrm{~d}, J=2.46 \mathrm{~Hz}, 1 \mathrm{H}, \mathrm{Ar}-\mathrm{H} 2), 7.18$ (dd, J = 8.69, 2.46 Hz, 1H, Ar-H6), $4.88\left(\mathrm{~s}, 2 \mathrm{H}, \mathrm{OCH}_{2}\right)$; LC-MS (ESI) $\mathrm{m} / z 251.9(\mathrm{M}+)^{-}, 253.9(\mathrm{M}+2)^{-}$; Anal. Calcd for $\left(\mathrm{C}_{11} \mathrm{H}_{9} \mathrm{ClN}_{2} \mathrm{O}_{3}\right)$ : C, 52.29; H, 3.59; Cl, 14.03; N, 11.09; Found: C, 52.15; H, 3.24; Cl, 14.40; N, 11.12.

\subsection{General Procedure for the Synthesis of Ethyl [(2,3-Di/monochloro-4-formyl)phenoxy]acetates 14a,b [41]}

To a cold mixture of 4-hydroxybenzaldehydes $\mathbf{1 a}, \mathbf{b}(0.01 \mathrm{~mol})$ and $\mathrm{K}_{2} \mathrm{CO}_{3}(0.015 \mathrm{~mol})$ in DMF $(20 \mathrm{~mL})$, was added ethyl bromoacetate $(0.012 \mathrm{~mol})$ at $5-10^{\circ} \mathrm{C}$. The reaction mixture was stirred for $1 \mathrm{hr}$ then treated with water $(20 \mathrm{~mL})$ and extracted in DCM $(2 \times 25 \mathrm{~mL})$. The combined organic extract was washed with water and brine then dried over anhydrous $\mathrm{MgSO}_{4}$. After evaporation in vacuo, the residue was treated with hexane to give the esters $\mathbf{1 4 a}, \mathbf{b}$.

Ethyl [(2,3-dichloro-4-formyl)phenoxy]acetate (14a): pale brown solid (2.4 g, 82\%), m.p. $134-138{ }^{\circ} \mathrm{C}$. ${ }^{1} \mathrm{H}-\mathrm{NMR}\left(300 \mathrm{MHz}, \mathrm{CDCl}_{3}\right) \delta_{\mathrm{H}} \operatorname{ppm} 10.39$ (s, 1H, CHO); 7.87 (d, J=8.78 Hz, 1H, Ar-H), $6.84(\mathrm{~d}$, $J=8.78 \mathrm{~Hz}, 1 \mathrm{H}, \mathrm{Ar}-\mathrm{H}), 4.83\left(\mathrm{~s}, 2 \mathrm{H}, \mathrm{OCH}_{2}\right), 4.31\left(\mathrm{q}, J=7.14 \mathrm{~Hz}, 2 \mathrm{H}, \mathrm{CH}_{2}\right), 1.32\left(\mathrm{t}, J=7.13 \mathrm{~Hz}, 3 \mathrm{H}, \mathrm{CH}_{3}\right)$.

Ethyl [(2-chloro-4-formyl)phenoxy]acetate (14b): clear liquid (4.3 g, 94\% yield); ${ }^{1} \mathrm{H}-\mathrm{NMR}(300 \mathrm{MHz}$, DMSO- $\left.d_{6}\right) \delta_{\mathrm{H}}$ ppm $9.88(\mathrm{~s}, 1 \mathrm{H}, \mathrm{CHO}), 7.93-8.05(\mathrm{~m}, 1 \mathrm{H}, \mathrm{Ar}-\mathrm{H} 3), 7.86$ (d, J = 8.50 Hz, 1H, Ar-H5), 7.30 $(\mathrm{d}, J=8.50 \mathrm{~Hz}, 1 \mathrm{H}, \mathrm{Ar}-\mathrm{H} 6), 5.09\left(\mathrm{~s}, 2 \mathrm{H}, \mathrm{CH}_{2}\right), 4.25$ (q, J = 7.04 Hz, 2H), $1.23\left(\mathrm{t}, J=7.06 \mathrm{~Hz}, 3 \mathrm{H}, \mathrm{CH}_{3}\right)$.

\subsection{General Procedure for the Synthesis of Ethyl 4-[(Di/monochloro-4-formyl)phenoxy]butanoates 14c-e [41]}

To a solution of $1 \mathrm{a}-\mathbf{c}(0.018 \mathrm{~mol})$ in $N$-methylpyrrolidone $(\mathrm{NMP}, 30 \mathrm{~mL})$ was added $\mathrm{K}_{2} \mathrm{CO}_{3}$ $(0.0275 \mathrm{~mol})$ and $\mathrm{KI}(1.8 \mathrm{mmol})$ at room temperature. After stirring for $30 \mathrm{~min}$, ethyl 4-bromobutyrate $(3.5 \mathrm{~g}, 0.0183 \mathrm{~mol})$ was added, and the reaction was continued for $7 \mathrm{~h}$ at $60^{\circ} \mathrm{C}$. The reaction mixture was diluted with water $(50 \mathrm{~mL})$ and extracted with DCM $(3 \times 75 \mathrm{~mL})$. The combined organic extract was washed with water then brine and dried over anhydrous $\mathrm{Na}_{2} \mathrm{SO}_{4}$. The solvent was removed under reduced pressure, and the crude product was purified by column chromatography $(6 \%$ EtOAc in hexane) to give the products $14 \mathbf{c}-\mathbf{e}$. 
Ethyl 4-[(2,3-dichloro-4-formyl)phenoxy]butanoate (14c): white solid (4 g, 72\%), m.p. $163-165{ }^{\circ} \mathrm{C} .{ }^{1} \mathrm{H}-\mathrm{NMR}$ $\left(300 \mathrm{MHz}, \mathrm{DMSO}-d_{6}\right) \delta_{\mathrm{H}} \mathrm{ppm} 10.19(\mathrm{~s}, 1 \mathrm{H}, \mathrm{CHO}), 7.84(\mathrm{~d}, J=8.88 \mathrm{~Hz}, 1 \mathrm{H}, \mathrm{Ar}-\mathrm{H} 5), 7.32(\mathrm{~d}, J=8.78 \mathrm{~Hz}$, $1 \mathrm{H}, \mathrm{Ar}-\mathrm{H6}), 4.25\left(\mathrm{t}, J=6.23 \mathrm{~Hz}, 2 \mathrm{H}, \mathrm{CH}_{2}\right), 4.07\left(\mathrm{q}, J=7.08 \mathrm{~Hz}, 2 \mathrm{H}, \mathrm{CH}_{2}\right), 2.51(\mathrm{t}, 2 \mathrm{H}$, Under DMSO), 2.04 (quin, $\left.J=6.77 \mathrm{~Hz}, 2 \mathrm{H}, \mathrm{CH}_{2}\right), 1.14\left(\mathrm{q}, J=6.31,3 \mathrm{H}, \mathrm{CH}_{3}\right.$ ).

Ethyl 4-[(2-chloro-4-formyl)phenoxy]butanoate (14d): clear liquid $(7.1 \mathrm{~g}, 82 \%) ;{ }^{1} \mathrm{H}-\mathrm{NMR}(300 \mathrm{MHz}$, DMSO- $\left.d_{6}\right) \delta_{\mathrm{H}}$ ppm $9.86(\mathrm{~s}, 1 \mathrm{H}, \mathrm{CHO}), 7.94(\mathrm{~s}, 1 \mathrm{H}, \mathrm{Ar}-\mathrm{H} 3), 7.88(\mathrm{~d}, J=8.50 \mathrm{~Hz}, 1 \mathrm{H}, \mathrm{Ar}-\mathrm{H} 6), 7.35$ $(\mathrm{d}, J=8.50 \mathrm{~Hz}, 1 \mathrm{H}, \mathrm{Ar}-\mathrm{H} 5), 4.22\left(\mathrm{t}, J=6.23 \mathrm{~Hz}, 2 \mathrm{H}, \mathrm{CH}_{2}\right), 4.07\left(\mathrm{q}, J=7.08 \mathrm{~Hz}, 2 \mathrm{H}, \mathrm{CH}_{2}\right), 2.39(2 \mathrm{H}$, under DMSO), $1.96-2.12\left(\mathrm{~m}, 2 \mathrm{H}, \mathrm{CH}_{2}\right), 1.18\left(\mathrm{t}, J=7.13 \mathrm{~Hz}, 3 \mathrm{H}, \mathrm{CH}_{3}\right)$.

Ethyl 4-[(3-chloro-4-formyl)phenoxy]butanoate (14e): white solid, (5 g, 82\%), m.p. $118-121{ }^{\circ} \mathrm{C} .{ }^{1} \mathrm{H}-\mathrm{NMR}$ $\left(300 \mathrm{MHz}, \mathrm{DMSO}-d_{6}\right) \delta_{\mathrm{H}} 10.19(\mathrm{~s}, 1 \mathrm{H}, \mathrm{CHO}), 7.83(\mathrm{~d}, J=8.78 \mathrm{~Hz}, 1 \mathrm{H}, \mathrm{Ar}-\mathrm{H} 5), 7.18(\mathrm{~d}, J=1.70 \mathrm{~Hz}$, $1 \mathrm{H}, \mathrm{Ar}-\mathrm{H} 3), 7.08(\mathrm{dd}, J=8.78,2.27 \mathrm{~Hz}, 1 \mathrm{H}, \mathrm{Ar}-\mathrm{H} 6), 4.10-4.20\left(\mathrm{~m}, 2 \mathrm{H}, \mathrm{CH}_{2}\right), 4.02-4.10\left(\mathrm{~m}, 2 \mathrm{H}, \mathrm{CH}_{2}\right)$, 2.41-2.49 (2H, under DMSO, $\left.\mathrm{CH}_{2}\right), 1.99\left(\mathrm{t}, J=6.80 \mathrm{~Hz}, 2 \mathrm{H}, \mathrm{CH}_{2}\right), 1.18\left(\mathrm{t}, J=7.13 \mathrm{~Hz}, 3 \mathrm{H}, \mathrm{CH}_{3}\right)$

3.14. General Procedure for the Synthesis of Ethyl [Di/monochloro-4-(4,5-dihydro-1H-imidazol-2-yl)phenoxy]acetate/butanoates 15a-e [44]

To a stirred solution of ethyl esters 14a-e $(8.6 \mathrm{mmol})$ in chloroform $(25 \mathrm{~mL})$, was added ethylenediamine at 0 to $5{ }^{\circ} \mathrm{C}$. After stirring for $30 \mathrm{~min}$ at room temperature, $\mathrm{N}$-bromosuccinimide was added at 0 to $5{ }^{\circ} \mathrm{C}$ over $20 \mathrm{~min}$. The reaction mixture was slowly warmed to room temperature and stirred for $16 \mathrm{~h} . \mathrm{NaHCO}_{3} 10 \%$ solution $(25 \mathrm{~mL})$ was added to quench the reaction, followed by extraction with chloroform $(3 \times 50 \mathrm{~mL})$. The combined organic extract was concentrated to afford crude product 15a-e.

Ethyl [2,3-dichloro-4-(4,5-dihydro-1H-imidazol-2-yl)phenoxy]acetate (15a): pale yellow solid (2.5 g, 91\%), m.p. $132-134{ }^{\circ} \mathrm{C} .{ }^{1} \mathrm{H}-\mathrm{NMR}\left(300 \mathrm{MHz}, \mathrm{DMSO}-d_{6}\right) \delta_{\mathrm{H}} 7.45(\mathrm{~d}, J=8.69 \mathrm{~Hz}, 1 \mathrm{H}, \mathrm{Ar}-\mathrm{H} 5), 7.12(\mathrm{~d}, J=8.78 \mathrm{~Hz}$, $1 \mathrm{H}, \mathrm{Ar}-\mathrm{H} 6), 6.79$ (brs, $1 \mathrm{H}, \mathrm{NH}), 5.03\left(\mathrm{~s}, 2 \mathrm{H}, \mathrm{OCH}_{2}\right), 4.18\left(\mathrm{q}, J=7.08 \mathrm{~Hz}, 2 \mathrm{H}, \mathrm{CH}_{2}\right), 3.59$ (brs, $4 \mathrm{H}$, imidazoline- $\mathrm{H}), 1.22\left(\mathrm{t}, J=7.03 \mathrm{~Hz}, 3 \mathrm{H}, \mathrm{CH}_{3}\right)$.

Ethyl [2-chloro-4-(4,5-dihydro-1H-imidazol-2-yl)phenoxy]acetate (15b): greyish white solid (3.8 g, 66\%), m.p. $124-126{ }^{\circ} \mathrm{C} .{ }^{1} \mathrm{H}-\mathrm{NMR}\left(300 \mathrm{MHz}, \mathrm{DMSO}-d_{6}\right) \delta_{\mathrm{H}} 7.89(\mathrm{~s}, 1 \mathrm{H}, \mathrm{NH}), 7.73(\mathrm{~d}, J=8.69 \mathrm{~Hz}, 1 \mathrm{H}, \mathrm{Ar}-\mathrm{H} 6)$, 7.11 (brs, 1H, Ar-H3), $7.12(\mathrm{~d}, J=8.69 \mathrm{~Hz}, 1 \mathrm{H}, \mathrm{Ar}-\mathrm{H} 5), 4.98\left(\mathrm{~s}, 2 \mathrm{H}, \mathrm{OCH}_{2}\right) 4.18\left(\mathrm{q}, J=7.02 \mathrm{~Hz}, 2 \mathrm{H}, \mathrm{CH}_{2}\right)$, $3.60(\mathrm{~s}, 4 \mathrm{H}$, imidazoline- $\mathrm{H}) 1.22\left(\mathrm{t}, J=7.08 \mathrm{~Hz}, 3 \mathrm{H}, \mathrm{CH}_{3}\right)$.

Ethyl 4-[2,3-dichloro-4-(4,5-dihydro-1H-imidazol-2-yl)phenoxy]butanoate (15c): pale greyish white solid $(4 \mathrm{~g}, 89 \%) ;{ }^{1} \mathrm{H}-\mathrm{NMR}\left(300 \mathrm{MHz}, \mathrm{DMSO}-d_{6}\right) \delta_{\mathrm{H}} 7.48(\mathrm{~d}, J=8.59 \mathrm{~Hz}, 1 \mathrm{H}, \mathrm{Ar}-\mathrm{H} 6), 7.19(\mathrm{~d}, J=8.88 \mathrm{~Hz}$, 1H, Ar-H5) 4.13-4.25 (m, 2H, $\left.\mathrm{CH}_{2}\right) 4.07\left(\mathrm{q}, J=6.89 \mathrm{~Hz}, 2 \mathrm{H}, \mathrm{CH}_{2}\right), 3.60(\mathrm{~m}, 4 \mathrm{H}$, imidazoline- $\mathrm{H}), 2.51$ ( $\mathrm{t}, 2 \mathrm{H}$, under DMSO), $1.94-2.10\left(\mathrm{~m}, 2 \mathrm{H}, \mathrm{CH}_{2}\right), 1.18\left(\mathrm{t}, J=6.76 \mathrm{~Hz}, 3 \mathrm{H}, \mathrm{CH}_{3}\right)$.

Ethyl 4-[2-chloro-4-(4,5-dihydro-1H-imidazol-2-yl)phenoxy]butanoate (15d): T pale greyish white solid (6.2 g, 76\%), m.p. $138-140{ }^{\circ} \mathrm{C} .{ }^{1} \mathrm{H}-\mathrm{NMR}\left(300 \mathrm{MHz}, \mathrm{DMSO}-d_{6}\right) \delta_{\mathrm{H}} 7.88(\mathrm{~d}, J=1.51 \mathrm{~Hz}, 1 \mathrm{H}, \mathrm{Ar}-\mathrm{H} 3), 7.77$ $(\mathrm{dd}, J=8.64,1.65 \mathrm{~Hz}, 1 \mathrm{H}, \mathrm{Ar}-\mathrm{H} 5), 7.22(\mathrm{~d}, J=8.59 \mathrm{~Hz}, 1 \mathrm{H}, \mathrm{Ar}-\mathrm{H} 6), 4.14\left(\mathrm{t}, J=6.98 \mathrm{~Hz}, 2 \mathrm{H}, \mathrm{CH}_{2}\right), 4.05$ (q, $\left.J=7.12 \mathrm{~Hz}, 2 \mathrm{H}, \mathrm{CH}_{2}\right), 3.62\left(\mathrm{~m}, 4 \mathrm{H}\right.$, imidazoline-H), 2.47 (under DMSO, $\left.2 \mathrm{H}, \mathrm{CH}_{2}\right), 2.01\left(\mathrm{~m}, 2 \mathrm{H}, \mathrm{CH}_{2}\right)$, $1.18\left(\mathrm{t}, J=7.08 \mathrm{~Hz}, 3 \mathrm{H}, \mathrm{CH}_{3}\right)$.

Ethyl 4-[3-chloro-4-(4,5-dihydro-1H-imidazol-2-yl)phenoxy]butanoate (15e): pale yellow solid (5 g, 87\%), m.p. $137-139^{\circ} \mathrm{C} .{ }^{1} \mathrm{H}-\mathrm{NMR}\left(300 \mathrm{MHz}, \mathrm{DMSO}-d_{6}\right) \delta_{\mathrm{H}} 7.52(\mathrm{~d}, J=8.69 \mathrm{~Hz}, 1 \mathrm{H}, \mathrm{Ar}-\mathrm{H} 5), 7.07(\mathrm{~d}, J=2.27 \mathrm{~Hz}$, $1 \mathrm{H}, \mathrm{Ar}-\mathrm{H} 2), 6.95(\mathrm{dd}, J=8.64,2.31 \mathrm{~Hz}, 1 \mathrm{H}, \mathrm{Ar}-\mathrm{H} 6), 3.99-4.10(\mathrm{~m}, 4 \mathrm{H}$, imidazoline-H), $3.60(\mathrm{~m}, 4 \mathrm{H}$, $\left.2 \mathrm{CH}_{2}\right), 2.45\left(\mathrm{t}, J=7.32 \mathrm{~Hz}, 2 \mathrm{H}, \mathrm{CH}_{2}\right), 1.97\left(\mathrm{t}, J=6.80 \mathrm{~Hz}, 2 \mathrm{H}, \mathrm{CH}_{2}\right), 1.18\left(\mathrm{t}, J=7.08 \mathrm{~Hz}, 3 \mathrm{H}, \mathrm{CH}_{3}\right)$.

3.15. General Procedure for the Synthesis of Ethyl [2,3-Dichloro-4-(1H-imidazol-2-yl)phenoxy]acetate/ butanoates 16a-e [44]

To a solution of $15 \mathrm{a}-\mathbf{e}(7.8 \mathrm{mmol})$ in DMSO $(25 \mathrm{~mL})$ was added $\mathrm{K}_{2} \mathrm{CO}_{3}(8.6 \mathrm{mmol})$ and diacetoxyiodobenzene $(8.6 \mathrm{mmol})$ at room temperature. The reaction mixture was stirred for $60 \mathrm{~min}$ in 
a dark place, and then water was added followed by extraction with DCM $(3 \times 50 \mathrm{~mL})$. The organic layer was dried over $\mathrm{Na}_{2} \mathrm{SO}_{4}$ and concentrated under reduced pressure. The residue was subjected to flash column chromatography (EtOAc 2:hexane 1) to afford the products 16a-e.

Ethyl [2,3-dichloro-4-(1H-imidazol-2-yl)phenoxy]acetate (16a): off-white solid (1.1g, 44\%), m.p. 193-194 ${ }^{\circ} \mathrm{C}$. ${ }^{1} \mathrm{H}-\mathrm{NMR}\left(300 \mathrm{MHz}, \mathrm{DMSO}-d_{6}\right) \delta_{\mathrm{H}} 12.31$ (brs, $\left.1 \mathrm{H}, \mathrm{NH}\right), 7.62(\mathrm{~d}, J=8.78 \mathrm{~Hz}, 1 \mathrm{H}, \mathrm{Ar}-\mathrm{H} 6), 7.06-7.26$ $\left(\mathrm{m}, 3 \mathrm{H}, \mathrm{Ar}-\mathrm{H}\right.$ and imidazole-H), $5.04\left(\mathrm{~s}, 2 \mathrm{H}, \mathrm{OCH}_{2}\right), 4.19\left(\mathrm{q}, J=7.05 \mathrm{~Hz}, 2 \mathrm{H}, \mathrm{CH}_{2}\right), 1.22(\mathrm{t}, J=7.08 \mathrm{~Hz}$, $\left.3 \mathrm{H}, \mathrm{CH}_{3}\right)$.

Ethyl [2-chloro-4-(1H-imidazol-2-yl)phenoxy]acetate (16b): greyish white solid $(1.5 \mathrm{~g}, 43 \%)$, m.p. $164-166{ }^{\circ} \mathrm{C}$. ${ }^{1} \mathrm{H}-\mathrm{NMR}\left(300 \mathrm{MHz}, \mathrm{DMSO}-d_{6}\right) \delta_{\mathrm{H}} 12.47$ (brs, $\left.1 \mathrm{H}, \mathrm{NH}\right), 8.00(\mathrm{~d}, J=2.08 \mathrm{~Hz}, 1 \mathrm{H}, \mathrm{Ar}-\mathrm{H} 3), 7.82(\mathrm{dd}, J=8.59$, $2.17 \mathrm{~Hz}, 1 \mathrm{H}, \mathrm{Ar}-\mathrm{H} 5), 4.96\left(\mathrm{~s}, 2 \mathrm{H}, \mathrm{OCH}_{2}\right), 7.15(\mathrm{~m}, 3 \mathrm{H}, \mathrm{Ar}-\mathrm{H}$ and imidazole- $\mathrm{H}), 4.19(\mathrm{q}, J=7.08 \mathrm{~Hz}, 2 \mathrm{H}$, $\left.\mathrm{CH}_{2}\right) 1.22\left(\mathrm{t}, J=7.13 \mathrm{~Hz}, 3 \mathrm{H}, \mathrm{CH}_{3}\right)$.

Ethyl 4-[2,3-dichloro-4-(1H-imidazol-2-yl)phenoxy]butanoate (16c): off-white solid (2.3 g, 55.8\%), m.p. $226-227{ }^{\circ} \mathrm{C} .{ }^{1} \mathrm{H}-\mathrm{NMR}\left(300 \mathrm{MHz}, \mathrm{CDCl}_{3}\right) \delta_{\mathrm{H}} 10.19$ (brs, $\left.1 \mathrm{H}, \mathrm{NH}\right), 8.14(\mathrm{~d}, J=8.88 \mathrm{~Hz}, 1 \mathrm{H}, \mathrm{Ar}-\mathrm{H} 6)$, $7.21\left(\mathrm{~s}, 2 \mathrm{H}\right.$, imidazole-H), $6.98(\mathrm{~d}, J=8.97 \mathrm{~Hz}, 1 \mathrm{H}, \mathrm{Ar}-\mathrm{H} 5), 4.00-4.34\left(\mathrm{~m}, 4 \mathrm{H}, 2 \mathrm{CH}_{2}\right), 2.61(\mathrm{t}, J=7.18 \mathrm{~Hz}$, $2 \mathrm{H}, \mathrm{CH}_{2}$ ), 2.21 (quin, $\left.J=6.61 \mathrm{~Hz}, 2 \mathrm{H}, \mathrm{CH}_{2}\right), 1.16-1.44\left(\mathrm{~m}, 3 \mathrm{H}, \mathrm{CH}_{3}\right.$ ).

Ethyl 4-[2-chloro-4-(1H-imidazol-2-yl)phenoxy]butanoate (16d): greyish white solid (3.4 g, 57\%), m.p. $179-182{ }^{\circ} \mathrm{C} .{ }^{1} \mathrm{H}-\mathrm{NMR}\left(300 \mathrm{MHz}, \mathrm{DMSO}-d_{6}\right) \delta_{\mathrm{H}} \mathrm{ppm} 12.44(\mathrm{brs}, 1 \mathrm{H}, \mathrm{NH}), 7.98(\mathrm{~d}, J=1.98 \mathrm{~Hz}$, $1 \mathrm{H}, \mathrm{Ar}-\mathrm{H} 3), 7.85$ (dd, J = 8.59, $1.98 \mathrm{~Hz}, 1 \mathrm{H}, \mathrm{Ar}-\mathrm{H} 5), 7.23(\mathrm{~d}, J=8.69 \mathrm{~Hz}, 1 \mathrm{H}, \mathrm{Ar}-\mathrm{H} 6), 7.10$ (m, 2H, imidazole-H), 4.03-4.17 (m, 4H, 2 $\left.\mathrm{CH}_{2}\right), 2.48$ (under DMSO, 2H, $\left.\mathrm{CH}_{2}\right), 1.94-2.08\left(\mathrm{~m}, 2 \mathrm{H}, \mathrm{CH}_{2}\right), 1.18(\mathrm{t}$, $\left.J=7.08 \mathrm{~Hz}, 3 \mathrm{H}, \mathrm{CH}_{3}\right)$.

Ethyl 4-[3-chloro-4-(1H-imidazol-2-yl)phenoxy]butanoate (16e): greyish white solid (2.58 g, 50\%), m.p. $168-172{ }^{\circ} \mathrm{C} .{ }^{1} \mathrm{H}-\mathrm{NMR}\left(300 \mathrm{MHz}, \mathrm{DMSO}-d_{6}\right) \delta_{\mathrm{H}} 7.68(\mathrm{~d}, J=8.69 \mathrm{~Hz}, 1 \mathrm{H}, \mathrm{Ar}-\mathrm{H} 5), 7.05-7.19(\mathrm{~m}, 3 \mathrm{H}$, Ar-H2 and imidazole-H), $7.00(\mathrm{dd}, J=8.69,2.55 \mathrm{~Hz}, 1 \mathrm{H}, \mathrm{Ar}-\mathrm{H} 6), 3.99-4.15\left(\mathrm{~m}, 4 \mathrm{H}, 2 \mathrm{CH}_{2}\right), 2.43-2.50$ (under DMSO, 2H, $\mathrm{CH}_{2}$ ), 1.99 (quin, $\left.J=6.75 \mathrm{~Hz}, 2 \mathrm{H}, \mathrm{CH}_{2}\right) 1.19\left(\mathrm{t}, J=7.13 \mathrm{~Hz}, 3 \mathrm{H}, \mathrm{CH}_{3}\right.$ ).

3.16. General Procedure for the Synthesis of 2-[Di/monochloro-4-(1H-imidazol-2-yl)phenoxy]acetic/butyric Acids 17a-e [43]

These compounds were prepared according to procedure described above for preparation of $7 \mathbf{a}-\mathbf{f}$, starting with esters $16 \mathbf{a}-\mathbf{e}(3.2 \mathrm{mmol})$.

2-[2,3-Dichloro-4-(1H-imidazol-2-yl)phenoxy]acetic acid (17a): off-white solid $(0.87 \mathrm{~g}, 82 \%)$, m.p. $>300{ }^{\circ} \mathrm{C}$ (dec.). ${ }^{1} \mathrm{H}-\mathrm{NMR}\left(300 \mathrm{MHz}, \mathrm{DMSO}-d_{6}\right) \delta_{\mathrm{H}} 15.08(\mathrm{brs}, 1 \mathrm{H}, \mathrm{OH}), 7.81(\mathrm{~s}, 1 \mathrm{H}, \mathrm{NH}), 7.70(\mathrm{~d}, J=8.88 \mathrm{~Hz}, 1 \mathrm{H}$, Ar-H6) $7.34(\mathrm{~d}, J=9.06 \mathrm{~Hz}, 1 \mathrm{H}, \mathrm{Ar}-\mathrm{H} 5), 7.0-7.01$ (m, 2H, imidazole-H), 5.00 (s, 2H,OCH $)^{2}, \mathrm{LC} / \mathrm{MS}$, $m / z 286.9(\mathrm{M}+1)^{+}, 288.9(\mathrm{M}+3)^{+}, 291.1(\mathrm{M}+5)^{+}$. Anal. Calcd for $\left(\mathrm{C}_{11} \mathrm{H}_{8} \mathrm{Cl}_{2} \mathrm{~N}_{2} \mathrm{O}_{3}\right): \mathrm{C}, 46.02 ; \mathrm{H}, 2.81$; $\mathrm{Cl}, 24.70 ; \mathrm{N}, 9.76$; Found: $\mathrm{C}, 46.21 ; \mathrm{H}, 3.02 ; \mathrm{Cl}, 24.34 ; \mathrm{N}, 9.49$.

[2-Chloro-4-(1H-imidazol-2-yl)phenoxy]acetic acid (17b): off-white solid $(1.2 \mathrm{~g}, 88.8 \%)$, m.p. $>300{ }^{\circ} \mathrm{C}$ (dec.); ${ }^{1} \mathrm{H}-\mathrm{NMR}\left(300 \mathrm{MHz}, \mathrm{DMSO}-d_{6}\right) \delta_{\mathrm{H}} 7.99(\mathrm{~d}, J=2.08 \mathrm{~Hz}, 1 \mathrm{H}, \mathrm{Ar}-\mathrm{H} 3), 7.82$ (dd, J = 8.69, $1.89 \mathrm{~Hz}$, 1H, Ar-H5), 7.02-7.20 (m, 3H, Ar-H6 and imidazole-H), 4.85 (s, 2H, $\left.\mathrm{OCH}_{2}\right) ; \mathrm{LC} / \mathrm{MS}, m / z 251.0\left(\mathrm{M}^{-}\right)$, $253.1(\mathrm{M}+2)^{-}$.

4-[2,3-Dichloro-4-(1H-imidazol-2-yl)phenoxy]butanoic acid (17c): off-white solid $\left(0.87\right.$ g, 82\%), m.p. $>300{ }^{\circ} \mathrm{C}$ (dec.); ${ }^{1} \mathrm{H}-\mathrm{NMR}\left(300 \mathrm{MHz}, \mathrm{DMSO}-d_{6}\right) \delta_{\mathrm{H}} 12.23$ (brs, $2 \mathrm{H}, \mathrm{NH}$ and $\left.\mathrm{OH}\right), 7.65(\mathrm{~d}, J=8.69 \mathrm{~Hz}, 1 \mathrm{H}$, Ar-H6), $7.25\left(\mathrm{~d}, J=8.69 \mathrm{~Hz}, 1 \mathrm{H}\right.$, Ar-H5), $7.15\left(\mathrm{~s}, 2 \mathrm{H}\right.$, imidazoline-H), $4.18\left(\mathrm{t}, J=5.95 \mathrm{~Hz}, 2 \mathrm{H}, \mathrm{OCH}_{2}\right)$, $2.44\left(\mathrm{t}, J=7.18 \mathrm{~Hz}, 2 \mathrm{H}, \mathrm{CH}_{2}\right), 1.93-2.08\left(\mathrm{~m}, 2 \mathrm{H}, \mathrm{CH}_{2}\right) ; \mathrm{LC} / \mathrm{MS}, \mathrm{m} / z 316.0(\mathrm{M}+1)^{+}, 318.0(\mathrm{M}+3)^{+}$, $320.0(\mathrm{M}+5)^{+}$.

4-[2-Chloro-4-(1H-imidazol-2-yl)phenoxy]butanoic acid (17d): pale brown solid $(1.5 \mathrm{~g}, 83 \%)$, m.p. $219-220{ }^{\circ} \mathrm{C}$; ${ }^{1} \mathrm{H}-\mathrm{NMR}\left(300 \mathrm{MHz}, \mathrm{DMSO}-d_{6}\right) \delta_{\mathrm{H}} 12.47$ (brs, $\left.1 \mathrm{H}, \mathrm{OH}\right), 12.20$ (brs, $\left.1 \mathrm{H}, \mathrm{NH}\right), 7.98(\mathrm{~d}, J=1.89 \mathrm{~Hz}, 1 \mathrm{H}$, Ar-H3), $7.85(\mathrm{~d}, J=8.59 \mathrm{~Hz}, 1 \mathrm{H}, \mathrm{Ar}-\mathrm{H} 6), 7.23(\mathrm{~d}, J=8.69 \mathrm{~Hz}, 1 \mathrm{H}, \mathrm{Ar}-\mathrm{H} 5), 7.11$ (s, 2H, imidazole-H), 4.12 
$\left(\mathrm{t}, J=6.23 \mathrm{~Hz}, 2 \mathrm{H}, \mathrm{OCH}_{2}\right), 2.42\left(\mathrm{t}, J=7.08 \mathrm{~Hz}, 2 \mathrm{H}, \mathrm{CH}_{2}\right), 1.95$ (quin, $J=6.93 \mathrm{~Hz}, 2 \mathrm{H}, \mathrm{CH}_{2}$ ); LC/MS (ESI), $m / z 281.1(\mathrm{M}+1)^{+}, 283.1(\mathrm{M}+3)^{+}$.

4-[3-Chloro-4-(1H-imidazol-2-yl)phenoxy]butanoic acid (17e): yellow solid (1.7 g, quantitative), m.p. 103-106 ${ }^{\circ} \mathrm{C}$; ${ }^{1} \mathrm{H}-\mathrm{NMR}\left(300 \mathrm{MHz}\right.$, DMSO- $\left.d_{6}\right) \delta_{\mathrm{H}} 12.14$ (brs, $\left.1 \mathrm{H}, \mathrm{NH}\right), 7.81(\mathrm{~d}, J=2.50 \mathrm{~Hz}, 1 \mathrm{H}, \mathrm{Ar}-\mathrm{H} 2), 7.67$ $(\mathrm{d}, J=8.69 \mathrm{~Hz}, 1 \mathrm{H}, \mathrm{Ar}-\mathrm{H} 5), 7.12(\mathrm{~d}, J=2.36 \mathrm{~Hz}, 2 \mathrm{H}$, imidazole-H), $7.01(\mathrm{dd}, J=8.73,2.50 \mathrm{~Hz}, 1 \mathrm{H}$, Ar-H6), $4.06\left(\mathrm{t}, J=6.42 \mathrm{~Hz}, 2 \mathrm{H}, \mathrm{OCH}_{2}\right.$ ), $2.39\left(\mathrm{t}, J=7.27 \mathrm{~Hz}, 2 \mathrm{H}, \mathrm{CH}_{2}\right), 1.95$ (quin, $J=6.80 \mathrm{~Hz}, 2 \mathrm{H}$, $\left.\mathrm{CH}_{2}\right) ; \mathrm{LC} / \mathrm{MS}, m / z 281.0(\mathrm{M}+1)^{+}, 283.1(\mathrm{M}+3)^{+}$; Anal. Calcd for $\left(\mathrm{C}_{13} \mathrm{H}_{13} \mathrm{ClN}_{2} \mathrm{O}_{3}\right): \mathrm{C}, 55.62 ; \mathrm{H}, 4.67$; $\mathrm{Cl}, 12.63 ; \mathrm{N}, 9.98$; Found: $\mathrm{C}, 55.87 ; \mathrm{H}, 5.01 ; \mathrm{Cl}, 12.99 ; \mathrm{N}, 9.88$.

\subsection{General Procedure for the Synthesis of 2,3-Di/monochloro-4-(3-hydroxypropoxy)benzaldehydes 18a-c [42]}

To a cooled stirred solution of the appropriate 4-hydroxybenzaldehyde (1a-c) $(0.031 \mathrm{~mol})$ and $\mathrm{K}_{2} \mathrm{CO}_{3}(0.157 \mathrm{~mol}), \mathrm{KI}(0.003 \mathrm{~mol})$ in DMF $(60 \mathrm{~mL})$, was added 3-chloro-1-propanol (6 g, $\left.0.062 \mathrm{~mol}\right)$ at $5-10{ }^{\circ} \mathrm{C}$. The mixture was stirred for $16 \mathrm{~h}$ at $70{ }^{\circ} \mathrm{C}$, then left to attain room temperature. Ice and water were added and the crude product was extracted with DCM $(3 \times 100 \mathrm{~mL})$. The combined organic extract was washed with water and brine, dried over anhydrous $\mathrm{MgSO}_{4}$. The crude compound was purified by flash chromatography using (EtOAc 1:hexane 4) to afford ethers 18a-c.

2,3-Dichloro-4-(3-hydroxypropoxy)benzaldehyde (18a): pale yellow liquid (6.2 g, 79\%); ${ }^{1} \mathrm{H}-\mathrm{NMR}(300 \mathrm{MHz}$, DMSO- $\left.d_{6}\right) \delta_{\mathrm{H}} 10.19$ (brs, $\left.1 \mathrm{H}, \mathrm{CHO}\right), 7.95$ (brs, $\left.1 \mathrm{H}, \mathrm{OH}\right), 7.32$ (d, J = 8.14 Hz, 1H, Ar-H6), 4.59-4.70 (m, $1 \mathrm{H}, \mathrm{Ar}-\mathrm{H} 5), 4.28\left(\mathrm{~m}, 2 \mathrm{H}, \mathrm{OCH}_{2}\right), 3.60\left(\mathrm{q}, \mathrm{J}=5.19 \mathrm{~Hz}, 2 \mathrm{H}, \mathrm{CH}_{2}\right), 1.84-2.02\left(\mathrm{~m}, 2 \mathrm{H}, \mathrm{CH}_{2}\right)$.

2-Chloro-4-(3-hydroxypropoxy)benzaldehyde (18b): pale yellow liquid $(9.5 \mathrm{~g}, 86.6 \%) ;{ }^{1} \mathrm{H}-\mathrm{NMR}(300 \mathrm{MHz}$, DMSO- $\left.d_{6}\right) \delta_{\mathrm{H}} 10.20(\mathrm{~s}, 1 \mathrm{H}, \mathrm{CHO}), 7.83(\mathrm{~d}, J=8.69 \mathrm{~Hz}, 1 \mathrm{H}, \mathrm{Ar}-\mathrm{H} 6) ; 7.18(\mathrm{~d}, J=2.27 \mathrm{~Hz}, 1 \mathrm{H}, \mathrm{Ar}-\mathrm{H} 3)$, $7.09\left(\mathrm{dd}, J=8.73,2.31 \mathrm{~Hz}, 1 \mathrm{H}, \mathrm{CH}_{5}\right), 4.61(\mathrm{t}, J=5.15 \mathrm{~Hz}, 1 \mathrm{H}, \mathrm{OH}), 4.19\left(\mathrm{t}, J=6.37 \mathrm{~Hz}, 2 \mathrm{H}, \mathrm{OCH}_{2}\right), 3.55$ $\left(\mathrm{q}, J=5.89 \mathrm{~Hz}, 2 \mathrm{H}, \mathrm{CH}_{2}\right), 1.88$ (quin, $J=6.26 \mathrm{~Hz}, 2 \mathrm{H}, \mathrm{CH}_{2}$ ).

3-Chloro-4-(3-hydroxypropoxy)benzaldehyde (18c): pale yellow liquid (9.5 g, 86.6\%). ${ }^{1} \mathrm{H}-\mathrm{NMR}(300 \mathrm{MHz}$, DMSO- $\left.d_{6}\right) \delta_{\mathrm{H}} 9.85(\mathrm{~s}, 1 \mathrm{H}, \mathrm{CHO}), 7.70-8.08(\mathrm{~m}, 2 \mathrm{H}, \mathrm{Ar}-\mathrm{H} 2, \mathrm{Ar}-\mathrm{H} 6), 7.34(\mathrm{~d}, J=8.50 \mathrm{~Hz}, 1 \mathrm{H}, \mathrm{Ar}-\mathrm{H} 5)$, $4.55-4.69$ (brs, $1 \mathrm{H}, \mathrm{OH}), 4.24\left(\mathrm{t}, J=6.18 \mathrm{~Hz}, 2 \mathrm{H}, \mathrm{OCH}_{2}\right), 3.53-3.68\left(\mathrm{~m}, 2 \mathrm{H}, \mathrm{CH}_{2}\right), 1.92$ (quin, $J=6.09 \mathrm{~Hz}$, $2 \mathrm{H}, \mathrm{CH}_{2}$ ).

3.18. General Procedure for the Synthesis of 3-[Di/monochloro-4-(4,5-dihydro-1H-imidazol-2-yl)phenoxy] propan-1-ols 19a-c [44]

These intermediates were prepared according to procedure described above for the preparation of 15a-e starting with the appropriate 4-(3-hydroxypropoxy)benzaldehyde derivatives 18a-c $(0.016 \mathrm{~mol})$.

3-[2,3-Dichloro-4-(4,5-dihydro-1H-imidazol-2-yl)phenoxy]propan-1-ol (19a): pale yellow liquid (4 g, 86\%); ${ }^{1} \mathrm{H}-\mathrm{NMR}\left(300 \mathrm{MHz}, \mathrm{DMSO}-d_{6}\right) \delta_{\mathrm{H}} 7.48(\mathrm{~d}, J=8.69 \mathrm{~Hz}, 1 \mathrm{H}, \mathrm{Ar}-\mathrm{H} 6), 7.20(\mathrm{~d}, J=8.78 \mathrm{~Hz}, 1 \mathrm{H}, \mathrm{Ar}-\mathrm{H} 5)$, $6.73(\mathrm{brs}, 1 \mathrm{H}, \mathrm{NH}), 4.62(\mathrm{brs}, 1 \mathrm{H}, \mathrm{OH}), 4.20(\mathrm{t}, J=6.00 \mathrm{~Hz}, 2 \mathrm{H}$, imidazoline- $\mathrm{H}), 3.78(\mathrm{t}, J=8.31 \mathrm{~Hz}, 2 \mathrm{H}$, imidazoline-H), 3.59 (brs, $2 \mathrm{H}, \mathrm{OCH}_{2}$ ), $3.44\left(\mathrm{t}, J=7.77 \mathrm{~Hz}, 2 \mathrm{H}, \mathrm{CH}_{2}\right), 1.93$ (quin, $J=6.72 \mathrm{~Hz}, 2 \mathrm{H}, \mathrm{CH}_{2}$ ).

3-[2-Chloro-4-(4,5-dihydro-1H-imidazol-2-yl)phenoxy]propan-1-ol (19b): pale yellow solid (7.74 g, 69.2\%), m.p. 88-91 ${ }^{\circ} \mathrm{C} .{ }^{1} \mathrm{H}-\mathrm{NMR}\left(300 \mathrm{MHz}, \mathrm{DMSO}-d_{6}\right) \delta_{\mathrm{H}} 7.85(\mathrm{~d}, J=1.98 \mathrm{~Hz}, 1 \mathrm{H}, \mathrm{Ar}-\mathrm{H} 3), 7.75(\mathrm{dd}, J=8.59$, $1.98 \mathrm{~Hz}, 1 \mathrm{H}, \mathrm{Ar}-\mathrm{H} 5) 7.20$ (d, J = $8.69 \mathrm{~Hz}, 1 \mathrm{H}, \mathrm{Ar}-\mathrm{H} 6), 6.93$ (brs, 1H, NH), 4.61 (brs, 1H, OH), 4.17 $(\mathrm{t}, J=6.18 \mathrm{~Hz}, 2 \mathrm{H}$, imidazoline-H), 3.75 (brs, $2 \mathrm{H}$, imidazoline- $\mathrm{H}), 3.59\left(\mathrm{t}, J=6.00 \mathrm{~Hz}, 2 \mathrm{H}, \mathrm{OCH}_{2}\right), 3.41$ (brs, $2 \mathrm{H}, \mathrm{CH}_{2}$ ), 1.90 (quin, $J=6.18 \mathrm{~Hz}, 2 \mathrm{H}, \mathrm{CH}_{2}$ ).

3-[3-Chloro-4-(4,5-dihydro-1H-imidazol-2-yl)phenoxy]propan-1-ol (19c): pale yellow liquid (10.3 g, 96.5\%); ${ }^{1} \mathrm{H}-\mathrm{NMR}\left(300 \mathrm{MHz}, \mathrm{DMSO}-d_{6}\right) \delta_{\mathrm{H}} 7.52(\mathrm{~d}, J=8.69 \mathrm{~Hz}, 1 \mathrm{H}, \mathrm{Ar}-\mathrm{H} 5), 7.05(\mathrm{~d}, J=2.27 \mathrm{~Hz}, 1 \mathrm{H}, \mathrm{Ar}-\mathrm{H} 2), 6.94$ $(\mathrm{dd}, J=8.64,2.41 \mathrm{~Hz}, 1 \mathrm{H}, \mathrm{Ar}-\mathrm{H} 6), 6.63(\mathrm{brs}, 1 \mathrm{H}, \mathrm{NH}), 4.59(\mathrm{~d}, J=4.44 \mathrm{~Hz}, 1 \mathrm{H}, \mathrm{OH}) 4.09(\mathrm{t}, J=6.33 \mathrm{~Hz}$, $2 \mathrm{H}$, imidazoline- $\mathrm{H}), 3.54(\mathrm{t}, J=6.18 \mathrm{~Hz}, 2 \mathrm{H}$, imidazoline- $\mathrm{H}), 3.48\left(\mathrm{t}, J=6.00 \mathrm{~Hz}, 2 \mathrm{H}, \mathrm{OCH}_{2}\right), 3.41$ (brs, $2 \mathrm{H}, \mathrm{CH}_{2}$ ), 1.85 (quin, $J=6.28 \mathrm{~Hz}, 2 \mathrm{H}, \mathrm{CH}_{2}$ ). 
3.19. General Procedure for the Synthesis of 3-[Di/monochloro-4-(1H-imidazol-2-yl)phenoxy]propan-1-ols 20a-c [44]

These intermediates were prepared following the same procedure described above for the preparation of $16 \mathbf{a}-\mathbf{c}$ starting with the appropriate $19 \mathbf{a}-\mathbf{c}(0.027 \mathrm{~mol})$.

3-[2,3-Dichloro-4-(1H-imidazol-2-yl)phenoxy]propan-1-ol (20a): pale yellow liquid (3.8 g, 50 \%); ${ }^{1} \mathrm{H}-\mathrm{NMR}$ $\left(300 \mathrm{MHz}, \mathrm{DMSO}-d_{6}\right) \delta_{\mathrm{H}} 12.29$ (brs, $\left.1 \mathrm{H}, \mathrm{NH}\right) 7.66(\mathrm{~d}, J=8.78 \mathrm{~Hz}, 1 \mathrm{H}, \mathrm{Ar}-\mathrm{H} 6), 7.26(\mathrm{~d}, J=8.88 \mathrm{~Hz}, 1 \mathrm{H}$, Ar-H5), 7.15 (m, 2H, imidazole-H), $4.62(\mathrm{brs}, 1 \mathrm{H}, \mathrm{OH}), 4.22\left(\mathrm{t}, \mathrm{J}=6.04 \mathrm{~Hz}, 2 \mathrm{H}, \mathrm{OCH}_{2}\right), 3.53-3.61(\mathrm{~m}, 2 \mathrm{H}$, $\left.\mathrm{CH}_{2}\right), 1.92\left(\mathrm{t}, \mathrm{J}=6.09 \mathrm{~Hz}, 2 \mathrm{H}, \mathrm{CH}_{2}\right)$.

3-[2-Chloro-4-(1H-imidazol-2-yl)phenoxy]propan-1-ol (20b): pale yellow liquid (3.2 g, 42\%); ${ }^{1} \mathrm{H}-\mathrm{NMR}$ $\left(300 \mathrm{MHz}, \mathrm{DMSO}-d_{6}\right) \delta_{\mathrm{H}} 12.43$ (brs, $\left.1 \mathrm{H}, \mathrm{NH}\right), 7.98$ (d, J = 1.98 Hz, 1H, Ar-H3), 7.85 (dd, J = 8.59, $1.98 \mathrm{~Hz}$, 1H, Ar-H5), 7.24 (d, J = 8.69 Hz, 1H, Ar-H6), 7.10 (brs, 2H, imidazole-H), 4.59 (t, J = 5.10 Hz, 1H, OH), $4.17\left(\mathrm{t}, J=6.23 \mathrm{~Hz}, 2 \mathrm{H}, \mathrm{OCH}_{2}\right) 3.60\left(\mathrm{q}, J=5.92 \mathrm{~Hz}, 2 \mathrm{H}, \mathrm{CH}_{2}\right), 1.90$ (quin, $J=6.1 \mathrm{~Hz}, 2 \mathrm{H}, \mathrm{CH}_{2}$ ).

3-[3-Chloro-4-(1H-imidazol-2-yl)phenoxy]propan-1-ol (20c): wine red liquid (7.1 g, 70\%); ${ }^{1} \mathrm{H}-\mathrm{NMR}$ $\left(300 \mathrm{MHz}, \mathrm{DMSO}-d_{6}\right) \delta_{\mathrm{H}} 12.16$ (brs, 1H, NH), 7.93 (d, J = 1.98 Hz, 1H, Ar-H2), 7.67 (d, J = 8.69 Hz, 1H, Ar-H5), 7.07-7.17 (m, 2H, imidazole-H), 7.01 (dd, J = 8.69, 2.36 Hz, 1H, Ar-H6), 4.60 (brs, 1H, OH), 4.11 $\left(\mathrm{t}, J=6.28 \mathrm{~Hz}, 2 \mathrm{H}, \mathrm{OCH}_{2}\right), 3.56\left(\mathrm{~d}, J=4.25 \mathrm{~Hz}, 2 \mathrm{H}, \mathrm{CH}_{2}\right), 1.87$ (quin, $J=6.2 \mathrm{~Hz}, 2 \mathrm{H}, \mathrm{CH}_{2}$ ).

3.20. General Procedure for the Synthesis of 3-[2,3-Di/monochloro-4-(1H-imidazol-2-yl)phenoxy]propanoic Acids 21a-c [42]

To a stirred solution of the appropriate alcohol $20 \mathrm{a}-\mathrm{c}(12.8 \mathrm{mmol})$ in acetone $(40 \mathrm{~mL})$, a solution of chromium trioxide $(68 \mathrm{mmol})$ in $\mathrm{H}_{2} \mathrm{O}(50 \mathrm{~mL})$ and $\mathrm{AcOH}(6 \mathrm{~mL})$ was added while keeping the temperature between $5-10{ }^{\circ} \mathrm{C}$. The mixture was stirred for $30 \mathrm{~min}$ at the same temperature then warmed up to room temperature for $16 \mathrm{~h}$. The reaction was monitored by LC-MS till complete disappearance of the starting material. Then the reaction mixture was treated with $\mathrm{NaHCO}_{3}$ and the $\mathrm{pH}$ was adjusted to 8 . The mixture was washed with DCM $(3 \times 50 \mathrm{~mL})$ and the aqueous layer was concentrated under reduced pressure to $50 \mathrm{~mL}$. Again, the $\mathrm{pH}$ was adjusted to $\mathrm{pH} 5(1.5 \mathrm{~N} \mathrm{HCl})$. The precipitated solid product was collected by filtration, washed with water and dried. Purification by crystallization from $\mathrm{MeOH}$ gave the required products $(21 \mathbf{a}-\mathbf{c})$.

3-[2,3-Dichloro-4-(1H-imidazol-2-yl)phenoxy]propanoic acids (21a): off-white solid (0.73 g, 18\%), m.p. $193-194{ }^{\circ} \mathrm{C}$. IR (KBr, $\left.v_{\max } \mathrm{cm}^{-1}\right)$ : 3585(NH), $3100(\mathrm{OH}), 1620(\mathrm{CO}), 1294,1023$ (C-O-C); ${ }^{1} \mathrm{H}-\mathrm{NMR}$ $\left(300 \mathrm{MHz}, \mathrm{DMSO}-d_{6}\right) \delta_{\mathrm{H}}$ 13.1(brs, $\left.1 \mathrm{H}, \mathrm{OH}\right), 12.4$ (brs, $\left.1 \mathrm{H}, \mathrm{NH}\right), 7.64(\mathrm{~d}, J=8.50 \mathrm{~Hz}, 1 \mathrm{H}, \mathrm{Ar}-\mathrm{H} 6), 7.27$ $(\mathrm{d}, J=8.69 \mathrm{~Hz}, 1 \mathrm{H}, \mathrm{Ar}-\mathrm{H} 5), 7.15\left(\mathrm{~s}, 2 \mathrm{H}\right.$, imidazole-H), $4.32\left(\mathrm{t}, J=8.2 \mathrm{~Hz}, 2 \mathrm{H}, \mathrm{OCH}_{2}\right), 2.67(\mathrm{t}, J=8.2 \mathrm{~Hz}$, $\left.2 \mathrm{H}, \mathrm{CH}_{2}\right)$; LC/MS: $m / z 300.0(\mathrm{M})^{-}, 302.0(\mathrm{M}+2)^{-}, 304.0(\mathrm{M}+4)^{-}$.

3-[2-Chloro-4-(1H-imidazol-2-yl)phenoxy]propanoic acid (21b): off-white solid (0.23 g, 44\%), m.p. $210-213{ }^{\circ} \mathrm{C}$. IR (KBr, $\left.v_{\max } \mathrm{cm}^{-1}\right)$ : $3443(\mathrm{NH}), 3142(\mathrm{OH}), 1687(\mathrm{CO}), 1269,1065(\mathrm{C}-\mathrm{O}-\mathrm{C}) ;{ }^{1} \mathrm{H}-\mathrm{NMR}(300 \mathrm{MHz}$, DMSO-d $)) \delta_{\mathrm{H}} 12.35$ (brs, 1H, OH), 7.97 (brs, 1H, NH), 7.86 (d, J = 8.59 Hz, 1H, Ar-H5), 7.27 $(\mathrm{d}, J=8.40 \mathrm{~Hz}, 1 \mathrm{H}, \mathrm{Ar}-\mathrm{H} 6), 7.11\left(\mathrm{~m}, 3 \mathrm{H}, \mathrm{Ar}-\mathrm{H} 3\right.$ and imidazole-H), $4.30\left(\mathrm{t}, J=7.1 \mathrm{~Hz}, 2 \mathrm{H}, \mathrm{CH}_{2}\right), 2.74$ $\left(\mathrm{t}, J=6.2 \mathrm{~Hz}, 2 \mathrm{H}, \mathrm{CH}_{2}\right)$; LC/MS: $m / z 267.0(\mathrm{M}+1), 269.1(\mathrm{M}+2)$; Anal. Calcd for $\left(\mathrm{C}_{13} \mathrm{H}_{11} \mathrm{ClN}_{2} \mathrm{O}_{3}\right)$ : C, 54.05; H, 4.16; Cl, 13.29; N, 10.50; Found: C, 53.79; H, 3.82; Cl, 13.61; N, 10.55.

3-[3-Chloro-4-(1H-imidazol-2-yl)phenoxy]propanoic acid (21c): off-white solid (0.6 g, 9.5\%), m.p. $208-210{ }^{\circ} \mathrm{C}$. IR (KBr, $\left.v_{\max } \mathrm{cm}^{-1}\right)$ : $3400(\mathrm{NH}), 3139(\mathrm{OH}), 1694(\mathrm{CO}), 1296,1092(\mathrm{C}-\mathrm{O}-\mathrm{C}) ;{ }^{1} \mathrm{H}-\mathrm{NMR}(300 \mathrm{MHz}$, DMSO- $\left.d_{6}\right) \delta_{\mathrm{H}} 13.0,12.21$ (two brs, each $1 \mathrm{H}, \mathrm{OH}$ and $\left.\mathrm{NH}\right), 7.67(\mathrm{~d}, J=8.69 \mathrm{~Hz}, 1 \mathrm{H}, \mathrm{Ar}-\mathrm{H} 5), 7.12$ $\left(\mathrm{m}, 3 \mathrm{H}, \mathrm{Ar}-\mathrm{H} 2\right.$ and imidazole-H), $7.01(\mathrm{~d}, J=7.08 \mathrm{~Hz}, 1 \mathrm{H}, \mathrm{Ar}-\mathrm{H} 6), 4.24\left(\mathrm{t}, J=5.17 \mathrm{~Hz}, 2 \mathrm{H}, \mathrm{OCH}_{2}\right), 2.70$ $\left(\mathrm{t}, J=5.43 \mathrm{~Hz}, 2 \mathrm{H}, \mathrm{CH}_{2}\right)$; LC/MS: $m / z 267.0(\mathrm{M}+1)^{-}, 269.0(\mathrm{M}+3)^{-}$. 


\subsection{RBC Morphological Antisickling Studies}

KAUS-4, KAUS-23 and KAUS-24, and clofibrate were tested for their effect on sickle RBC morphology as previously reported $[18,19,22]$. Briefly sickle RBCs were incubated under air in the absence or presence of $2 \mathrm{mM}$ concentration of test compound (solubilized in DMSO) at room temperature for $1 \mathrm{~h}$. Following, the suspension was incubated under hypoxic condition $(4 \%$ oxygen $/ 96 \%$ nitrogen) at $37^{\circ} \mathrm{C}$ for $3 \mathrm{~h}$. The suspension was fixed with $2 \%$ glutaraldehyde solution without exposure to air and then subjected to microscopic morphological analysis.

\subsection{Oxygen Equilibrium Curve Studies}

Normal blood samples (hematocrit 22\%) in the absence (control) or presence of $2 \mathrm{mM}$ concentration of the test KAUS compounds (solubilized in DMSO) were incubated at $37^{\circ} \mathrm{C}$ for $1.5 \mathrm{~h}$ and then subjected to OEC analysis using tonometry as previously described $[18,19,22]$. Briefly, the compound-treated blood samples is incubated in IL 237 tonometers (Instrumentation Laboratories, Inc. Lexington, MA, USA) for approximately $10 \mathrm{~min}$ at $37^{\circ} \mathrm{C}$, and allowed to equilibrate at oxygen tensions 7, 20, 40 and $60 \mathrm{mmHg}$. The samples were then aspirated into an ABL 700 Automated Blood Gas Analyzer (Radiometer) to determine the $\mathrm{pH}$, partial pressure of $\mathrm{CO}_{2}\left(\mathrm{pCO}_{2}\right)$, partial pressure of oxygen $\left(\mathrm{pO}_{2}\right)$, and $\mathrm{Hb}$ oxygen saturation values $\left(\mathrm{SO}_{2}\right)$. The measured values of $\mathrm{pO}_{2}(\mathrm{mmHg})$ and $\mathrm{SO}_{2}$ at each $\mathrm{pO}_{2}$ value were then subjected to a non-linear regression analysis using the program Scientist (Micromath, Salt Lake City, UT, USA) to estimate $\mathrm{P}_{50}$ and Hill coefficient values $\left(\mathrm{n}_{50}\right)$. Clofibrate was tested as a positive control, while DMSO was tested as negative control.

\subsection{Crystallization, Data Collection and Structure Determination of Deoxygenated $\mathrm{Hb}$ in Complex with KAUS-23}

Freshly prepared solution of KAUS-23 in DMSO was incubated with deoxygenated $\mathrm{Hb}(40 \mathrm{mg} / \mathrm{mL})$ for $30 \mathrm{~min}$ at $\mathrm{Hb}$ tetramer:KAUS-23 molar ratio of 1:10 at room temperature and then crystallized with $3.2 \mathrm{M}$ sulfate/phosphate precipitant, $\mathrm{pH} 6.8$ using the batch method as previously described $[18,19,22]$. Diffraction data was collected at $100 \mathrm{~K}$ on an R-axis IV++ image plate detector using $\mathrm{CuK} \alpha \mathrm{X}$-ray $(\lambda=1.5417)$ from a Rigaku Micro-Max ${ }^{\mathrm{TM}}-007 \mathrm{X}$-ray source equipped with Varimax confocal optics operating at $40 \mathrm{kV}$ and $20 \mathrm{~mA}$ (Rigaku, The Woodlands, TX, USA). Crystals were cryoprotected with $15 \%$ glycerol. The dataset was processed with the $\mathrm{d}^{*}$ trek software (v9.9.9.7, Rigaku Corporation, Tokyo, Japan) and the CCP4 suite of programs [45].

The isomorphous native human deoxygenated $\mathrm{Hb}$ tetramer structure (PDB code 2DN2) was used as the starting model to refine the structure, using both Phenix and CNS refinement programs [46,47]. Model building and correction were carried out using COOT [48,49]. A round of refinement showed a bound KAUS-23 molecule at the central water cavity. The symmetry-related site was poorly defined. Therefore, only one KAUS-23 molecule was built into the model and refined. Also, included in the final model are two molecules of sulfate ions, and 400 water molecules. The structure refined to a final Rfactor/Rfree of $19.68 / 24.92 \%$ at a resolution of $2.15 \AA$. The atomic coordinate and structure factor files have been deposited in the RCSB Protein Data Bank with accession codes 5KDQ. Detailed crystallographic and structural analysis parameters are reported in Table 3.

\section{Conclusions}

Aryloxyalkanoic acids that bind non-covalently to the $\alpha \operatorname{Trp} 14$ hydrophobic pocket of $\mathrm{Hb}$ have been shown to exhibit antisickling activities, while those that bind to the central water cavity of the protein in most instances showed the opposite effect [25-29]. The novel KAUS molecules were designed to have an imidazole pharmacophore, which was expected to increase hydrophobic interactions at the $\alpha \operatorname{Trp} 14$ binding site and result in enhanced antisickling activity. However, our structural modifications did not work as anticipated, as these compounds appear to bind to the central water cavity instead, stabilizing the $\mathrm{T}$-state $\mathrm{Hb}$ and resulting mostly in a decrease in $\mathrm{Hb}$ affinity for oxygen. Considering that 
compounds that decrease $\mathrm{Hb}$ affinity for oxygen and enhance $\mathrm{O} 2$ delivery to tissues have been studied to treat hypoxic- or ischemic-related diseases [50-57], this series of compounds may potentially be useful. For example, RSR-13 and several of its analogs that bind to the central water cavity of $\mathrm{Hb}$ and significantly decrease $\mathrm{Hb}$ affinity for oxygen $\left(\Delta \mathrm{P}_{50}\right.$ of $20-30 \mathrm{mmHg}$ at $\left.2 \mathrm{mM}\right)$ have been the subject of investigation for stroke, wound healing, and as a radiation enhancer in the radiotherapy of hypoxic tumors, adjuncts for $\mathrm{Hb}$ based oxygen carriers, nitric oxide, carbon monoxide and other non-oxygen therapeutic gases [50-57]. These compounds were designed based on clofibrate atomic interaction with $\mathrm{Hb}[2,30-32,37,57,58]$. Like clofibrate, the KAUS compounds bind to the central water cavity of $\mathrm{Hb}$ and weakly decrease $\mathrm{Hb}$ affinity for oxygen by stabilizing the T-state. The structure provides direction and approach for designing a new class of potent $\mathrm{Hb}$ allosteric compounds that decrease $\mathrm{Hb}$ affinity for oxygen. We note that the alkanoic acid moiety of KAUS-23 is close to the side-chains of $\alpha \operatorname{Tyr} 140, \alpha$ Pro95, $\alpha$ Va196, $\beta$ Trp37 and $\alpha$ Lys99; residues that are known to move significantly during the $\mathrm{T} \leftrightarrow \mathrm{R}$ transition. By incorporating another phenyl group between the methoxyphenyl and the alkanoic acid not only would allow increased hydrophobic interactions with these residues, but also extend the carboxylate to potentially form salt-bridge/hydrogen-bond interactions with $\alpha$ Lys 99 . We therefore anticipate these interactions to lock the residues in the T-state conformation and lead to further stabilization of the $\mathrm{T}$-state with a concomitant decrease in $\mathrm{Hb}$ affinity for oxygen.

Besides aryloxyalkanoic acids, non-acidic halogenated benzene derivatives or toluene are also known to bind to the $\alpha \operatorname{Trp} 14$ hydrophobic pocket $[26,33,59]$. However, unlike the aryloxyalkanoic acids, the halogenated benzenes or toluene bind exclusively to the $\alpha \operatorname{Trp} 14$ site. It is not obvious what is directing the KAUS compounds into the central water cavity because modelling KAUS-23 at the $\alpha$ Trp14 binding pocket (Figure 2b) suggested a more favorable binding when compared to its actual binding in the central water cavity (see Supplementary Material). We speculate that like the large number of $\mathrm{Hb}$ effectors with carboxylate moiety [29-32], the central water cavity which is lined with several positive residues is acting like a sink to attract these carboxylate compounds. As part of our future investigations, we plan to modify or eliminate the acidic moieties from the KAUS compounds, which would likely lead to the desired interactions at the $\alpha \operatorname{Trp} 14$ site, and result in corresponding antisickling activity.

Supplementary Materials: Supplementary materials can be accessed at: http://www.mdpi.com/1420-3049/21/ $8 / 1057 /$ s1.

Acknowledgments: This project was funded by the National Plan for Science, Technology and Innovation (MAARIFAH)-King Abdulaziz City for Science and Technology-the Kingdom of Saudi Arabia award number (BIO1253-03-10), NIH/NIMHD grant MD009124 (MKS, OA); NIH/NIDDK grant R01DK084188 (OA). Structural biology resources were provided in part by NIH grant CA16059 to the VCU Massey Cancer Center. The authors also, acknowledge with thanks Science and Technology Unit, King Abdulaziz University for technical support.

Author Contributions: M.K.S., A.M.O., M.E.E.-A., M.A.M. and M.H.A. conceived and designed the experiments; A.M.O., F.H.A.B. and M.E.E.-A. synthesized the compounds; M.S.G. and O.A. performed the Oxygen Equilibrium Curve Studies and antisickling experiments; M.H.A. and M.K.S. determined the crystal structure; M.K.S., A.M.O. M.E.E.-A. and O.A. analyzed the data; M.K.S., A.M.O., M.E.E.-A., O.A., F.H.A.B. and M.H.A. contributed reagents/materials/analysis tools; M.K.S., A.M.O., M.E.E.-A., M.A.M., O.A. and M.H.A. wrote the paper.

Conflicts of Interest: The authors declare no conflict of interest.

\section{References}

1. Safo, M.K.; Ahmed, M.H.; Ghatge, M.S.; Boyiri, T. Hemoglobin-ligand binding: Understanding Hb function and allostery on atomic level. Biochim. Biophys. Acta 2011, 1814, 797-809. [CrossRef] [PubMed]

2. Safo, M.K.; Bruno, S. Allosteric Effectors of Hemoglobin: Past, Present and Future. In Chemistry and Biochemistry of Oxygen Therapeutics: From Transfusion to Artificial Blood; Mozzarelli, A., Bettati, S., Eds.; John Wiley and Sons, Ltd.: West Sussex, K, 2011; pp. 285-300.

3. Habara, A.; Steinberg, M.H. Minireview: Genetic basis of heterogeneity and severity in sickle cell disease. Exp. Biol. Med. (Maywood) 2016, 241, 689-696. [CrossRef] [PubMed] 
4. Akinsheye, I.; Klings, E.S. Sickle cell anemia and vascular dysfunction: The nitric oxide connection. J. Cell. Physiol. 2010, 224, 620-625. [CrossRef] [PubMed]

5. De Franceschi, L. Pathophisiology of sickle cell disease and new drugs for the treatment. Mediterr. J. Hematol. Infect. Dis. 2009, 1. [CrossRef] [PubMed]

6. Turhan, A.; Weiss, L.A.; Mohandas, N.; Coller, B.S.; Frenette, P.S. Primary role for adherent leukocytes in sickle cell vascular occlusion: A new paradigm. Proc. Natl. Acad. Sci. USA 2002, 99, 3047-3051. [CrossRef] [PubMed]

7. Jensen, F.B. The dual roles of red blood cells in tissue oxygen delivery: Oxygen carriers and regulators of local blood flow. J. Exp. Biol. 2009, 212, 3387-3393. [CrossRef] [PubMed]

8. Rogers, S.C.; Ross, J.G.; d'Avignon, A.; Gibbons, L.B.; Gazit, V.; Hassan, M.N.; McLaughlin, D.; Griffin, S.; Neumayr, T.; Debaun, M.; et al. Sickle hemoglobin disturbs normal coupling among erythrocyte O2 content, glycolysis, and antioxidant capacity. Blood 2013, 121, 1651-1662. [CrossRef] [PubMed]

9. Zhang, Y.; Berka, V.; Song, A.; Sun, K.; Wang, W.; Zhang, W.; Ning, C.; Li, C.; Zhang, Q.; Bogdanov, M.; et al. Elevated sphingosine-1-phosphate promotes sickling and sickle cell disease progression. J. Clin. Investig. 2014, 124, 2750-2761. [CrossRef] [PubMed]

10. Safo, M.K.; Kato, G.J. Therapeutic strategies to alter the oxygen affinity of sickle hemoglobin. Hematol. Oncol. Clin. N. Am. 2014, 28, 217-231. [CrossRef] [PubMed]

11. Harrington, D.J.; Adachi, K.; Royer, W.E. Crystal structure of deoxy-human hemoglobin beta6 Glu $\rightarrow$ Trp. Implications for the structure and formation of the sickle cell fiber. J. Biol. Chem. 1998, 273, 32690-32696. [CrossRef] [PubMed]

12. Harrington, D.J.; Adachi, K.; Royer, W.E. The high resolution crystal structure of deoxyhemoglobin S. J. Mol. Biol. 1997, 272, 398-407. [CrossRef] [PubMed]

13. Cretegny, I.; Edelstein, S.J. Double strand packing in hemoglobin S fibers. J. Mol. Biol. 1993, 230, $733-738$. [CrossRef] [PubMed]

14. Watowich, S.J.; Gross, L.J.; Josephs, R. Analysis of the intermolecular contacts within sickle hemoglobin fibers: Effect of site-specific substitutions, fiber pitch, and double-strand disorder. J. Struct. Biol. 1993, 111, 161-179. [CrossRef] [PubMed]

15. Edelstein, S.J. Molecular topology in crystals and fibers of hemoglobin S. J. Mol. Biol. 1981, 150, 557-575. [CrossRef]

16. Bunn, H.F.; Forget, B.G. Hemoglobin-Molecular, Genetic and Clinical Aspects; W.B. Saunders Company: Philadelphia, PA, USA, 1986; pp. 502-564.

17. Nagel, R.L.; Johnson, J.; Bookchin, R.M.; Garel, M.C.; Rosa, J.; Schiliro, G.; Wajcman, H.; Labie, D.; Moo-Penn, W.; Castro, O. Beta-Chain contact sites in the haemoglobin S polymer. Nature 1980, 283, 832-834. [CrossRef] [PubMed]

18. Abdulmalik, O.; Ghatge, M.S.; Musayev, F.N.; Parikh, A.; Chen, Q.; Yang, J.; Nnamani, I.N.; Danso-Danquah, R.; Eseonu, D.N.; Asakura, K.; et al. Crystallographic analysis of human hemoglobin elucidates the structural basis of the potent and dual antisickling activity of pyridyl derivatives of vanillin. Acta Crystallogr. Sect. D Biol. Crystallogr. 2011, 67, 920-928. [CrossRef] [PubMed]

19. Abdulmalik, O.; Safo, M.K.; Chen, Q.; Yang, J.; Brugnara, C.; Ohene-Frempong, K.; Abraham, D.J.; Asakura, T. 5-Hydroxymethyl-2-Furfural Modifies Intracellular Sickle Haemoglobin and Inhibits Sickling of Red Blood Cells. Br. J. Haematol. 2005, 128, 552-561. [CrossRef] [PubMed]

20. Safo, M.K.; Abdulmalik, O.; Danso-Danquah, R.; Burnett, J.C.; Nokuri, S.; Joshi, G.S.; Musayev, F.N.; Asakura, T.; Abraham, D.J. Structural basis for the potent antisickling effect of a novel class of five-membered heterocyclic aldehydic compounds. J. Med. Chem. 2004, 47, 4665-4676. [CrossRef] [PubMed]

21. Beddell, C.R.; Goodford, P.J.; Kneen, G.; White, R.D.; Wilkinson, S.; Wootton, R. Substituted benzaldehydes designed to increase the oxygen affinity of human haemoglobin and inhibit the sickling of sickled erythrocytes. Br. J. Pharmacol. 1984, 82, 397-407. [CrossRef] [PubMed]

22. Omar, A.M.; Mahran, M.A.; Ghatge, M.S.; Chowdhury, N.; Bamane, F.H.; El-Araby, M.E.; Abdulmalik, O.; Safo, M.K. Identification of a novel class of covalent modifiers of hemoglobin as potential antisickling agents. Org. Biomol. Chem. 2015, 13, 6353-6370. [CrossRef] [PubMed]

23. Park, S.; Hayes, B.L.; Marankan, F.; Mulhearn, D.C.; Wanna, L.; Mesecar, A.D.; Santarsiero, B.D.; Johnson, M.E.; Venton, D.L. Regioselective covalent modification of hemoglobin in search of antisickling agents. J. Med. Chem. 2003, 46, 936-953. [CrossRef] [PubMed] 
24. Nakagawa, A.; Lui, F.E.; Wassaf, D.; Yefidoff-Freedman, R.; Casalena, D.; Palmer, M.A.; Meadows, J.; Mozzarelli, A.; Ronda, L.; Abdulmalik, O.; et al. Identification of a Small Molecule that Increases Hemoglobin Oxygen Affinity and Reduces SS Erythrocyte Sickling. ACS Chem. Biol. 2014, 9, 2318-2325. [CrossRef] [PubMed]

25. Abraham, D.J.; Mehanna, A.S.; Williams, F.L. Design, synthesis, and testing of potential antisickling agents. 1. Halogenated benzyloxy and phenoxy acids. J. Med. Chem. 1982, 25, 1015-1017. [CrossRef] [PubMed]

26. Abraham, D.J.; Perutz, M.F.; Phillips, S.E. Physiological and x-ray studies of potential antisickling agents. Proc. Natl. Acad. Sci. USA 1983, 80, 324-328. [CrossRef] [PubMed]

27. Abraham, D.J.; Kennedy, P.E.; Mehanna, A.S.; Patwa, D.C.; Williams, F.L. DesiDesign, synthesis, and testing of potential antisickling agents. 4. Structure-activity relationships of benzyloxy and phenoxy acids. J. Med. Chem. 1984, 27, 967-978. [CrossRef] [PubMed]

28. Patwa, D.C.; Abraham, D.J.; Hung, T.C. Design, synthesis, and testing of potential antisickling agents. 6. Rheologic studies with active phenoxy and benzyloxy acids. Blood Cells 1987, 12, 589-601. [PubMed]

29. Mehanna, A.S.; Abraham, D.J. Comparison of crystal and solution hemoglobin binding of selected antigelling agents and allosteric modifiers. Biochemistry 1990, 29, 3944-3952. [CrossRef] [PubMed]

30. Safo, M.K.; Moure, C.M.; Burnett, J.C.; Joshi, G.S.; Abraham, D.J. High-resolution crystal structure of deoxy hemoglobin complexed with a potent allosteric effector. Protein Sci. 2001, 10, 951-957. [CrossRef] [PubMed]

31. Lalezari, I.; Lalezari, P.; Poyart, C.; Marden, M.; Kister, J.; Bohn, B.; Fermi, G.; Perutz, M.F. New effectors of human hemoglobin: Structure and function. Biochemistry 1990, 29, 1515-1523. [CrossRef] [PubMed]

32. Perutz, M.F.; Poyart, C. Bezafibrate lowers oxygen affinity of haemoglobin. Lancet 1983, 2, 881-882. [CrossRef]

33. Safo, M.K.; Abdulmalik, O.; Lin, H.R.; Asakura, T.; Abraham, D.J. Structures of R- and T-State Hemoglobin Bassett: Elucidating the Structural Basis for the Low Oxygen Affinity of a Mutant Hemoglobin. Acta Crystallogr. Sect. D Biol. Crystallogr. 2005, 61, 156-162. [CrossRef] [PubMed]

34. Safo, M.K.; Abraham, D.J. X-ray crystallography of hemoglobins. Methods Mol. Med. 2003, 82, 1-19. [PubMed]

35. Park, S.Y.; Yokoyama, T.; Shibayama, N.; Shiro, Y.; Tame, J.R. 1.25 A resolution crystal structures of human haemoglobin in the oxy, deoxy and carbonmonoxy forms. J. Mol. Biol. 2006, 360, 690-701. [CrossRef] [PubMed]

36. Perutz, M.F.; Fermi, G.; Poyart, C.; Pagnier, J.; Kister, J. A novel allosteric mechanism in haemoglobin. Structure of bovine deoxyhaemoglobin, absence of specific chloride-binding sites and origin of the chloride-linked Bohr effect in bovine and human haemoglobin. J. Mol. Biol. 1993, 233, 536-545. [CrossRef] [PubMed]

37. Perutz, M.F.; Fermi, G.; Abraham, D.J.; Poyart, C.; Bursaux, E. Hemoglobin as a receptor of drugs and peptides: X-ray studies of the stereochemistry of binding. J. Am. Chem. Soc. 1986, 108, 1064-1078. [CrossRef]

38. Yokoyama, T.; Neya, S.; Tsuneshige, A.; Yonetani, T.; Park, S.Y.; Tame, J.R. R state haemoglobin with low oxygen affinity, crystal structures of deoxy human and carbonmonoxy horse haemoglobin bound to the effector molecule L35. J. Mol. Biol. 2006, 2006, 356, 790-801. [CrossRef] [PubMed]

39. Abraham, D.J.; Safo, M.K.; Boyiri, T.; Danso-Danquah, R.E.; Kister, J.; Poyart, C. How allosteric effectors can bind to the same protein residue and produce opposite shifts in the allosteric equilibrium. Biochemistry 1995, 34, 15006-15020. [CrossRef] [PubMed]

40. Jones, C.D.; Winter, M.A.; Hirsch, K.S.; Stamm, N.; Taylor, H.M.; Holden, H.E.; Davenport, J.D.; Krumkalns, E.V.; Suhr, R.G. Estrogen synthetase inhibitors. 2. Comparison of the in vitro aromatase inhibitory activity for a variety of nitrogen heterocycles substituted with diarylmethane or diarylmethanol groups. J. Med. Chem. 1990, 33, 416-429. [CrossRef] [PubMed]

41. Kaarsholm, N.C.; Birk, O.H.; Madsen, P.; Oestergaard, S.; Jakobsen, P.; Moeller, T.T. Pharmaceutical Preparations Comprising Insulin, Zinc Ions and a Zinc-Binding Ligand. WO2006082245 A1, 10 August 2006.

42. Jia, J. Facile synthesis of imidazo[1,2-a]pyridines via tandem reaction. Heterocycles 2010, 81, 185-194.

43. Sham, H.L.; Betebenner, D.A.; Chen, X.; Saldivar, A.; Vasavanonda, S.; Kemp f, D.J.; Plattner, J.J.; Norbeck, D.W. Synthesis and structure-activity relationships of a novel series of HIV-1 protease inhibitors encomp assing ABT-378 (Lopinavir). Bioorg. Med. Chem. Lett. 2002, 12, 1185-1187. [CrossRef]

44. Ishihara, M.; Togo, H. An efficient preparation of 2-imidazolines and imidazoles from aldehydes with molecular iodine and (diacetoxyiodo) benzene. Synlett 2006, 227-230. [CrossRef] 
45. Winn, M.D.; Ballard, C.C.; Cowtan, K.D.; Dodson, E.J.; Emsley, P.; Evans, P.R.; Keegan, R.M.; Krissinel, E.B.; Leslie, A.G.; McCoy, A.; et al. Overview of the CCP4 suite and current developments. Acta Crystallogr. D Biol. Crystallogr. 2011, 67, 235-242. [CrossRef] [PubMed]

46. Adams, P.D.; Afonine, P.V.; Bunkoczi, G.; Chen, V.B.; Echols, N.; Headd, J.J.; Hung, L.W.; Jain, S.; Kapral, G.J.; Grosse Kunstleve, R.W.; et al. The Phenix software for automated determination of macromolecular structures. Methods 2011, 55, 94-106. [CrossRef] [PubMed]

47. Brunger, A.T.; Adams, P.D.; Clore, G.M.; DeLano, W.L.; Gros, P.; Grosse-Kunstleve, R.W.; Jiang, J.S.; Kuszewski, J.; Nilges, M.; Pannu, N.S.; et al. Crystallography and NMR system: A new software suite for macromolecular structure determination. Acta Crystallogr. D Biol. Crystallogr. 1998, 54, 905-921. [CrossRef] [PubMed]

48. Emsley, P.; Lohkamp, B.; Scott, W.G.; Cowtan, K. Features and development of Coot. Acta Crystallogr. D Biol. Crystallogr. 2010, 66, 486-501. [CrossRef] [PubMed]

49. Emsley, P.; Cowtan, K. Coot: Model-building tools for molecular graphics. Acta Crystallogr. D Biol. Crystallogr. 2004, 60, 2126-2132. [CrossRef] [PubMed]

50. Khandelwal, S.R.; Randad, R.S.; Lin, P.S.; Meng, H.; Pittman, R.N.; Kontos, H.A.; Choi, S.C.; Abraham, D.J.; Schmidt-Ullrich, R. Enhanced oxygenation in vivo by allosteric inhibitors of hemoglobin saturation. Am. J. Physiol. 1993, 265, H1450-3. [PubMed]

51. Suh, J.H.; Stea, B.; Nabid, A.; Kresl, J.J.; Fortin, A.; Mercier, J.P.; Senzer, N.; Chang, E.L.; Boyd, A.P.; Cagnoni, P.J.; et al. Phase III study of efaproxiral as an adjunct to whole-brain radiation therapy for brain metastases. J. Clin. Oncol. 2006, 24, 106-114. [CrossRef] [PubMed]

52. Stea, B.; Suh, J.H.; Boyd, A.P.; Cagnoni, P.J.; Shaw, E. REACH Study Group Whole-brain radiotherapy with or without efaproxiral for the treatment of brain metastases: Determinants of response and its prognostic value for subsequent survival. Int. J. Radiat. Oncol. Biol. Phys. 2006, 64, 1023-1030. [CrossRef] [PubMed]

53. Scott, C.; Suh, J.; Stea, B.; Nabid, A.; Hackman, J. Improved survival, quality of life, and quality-adjusted survival in breast cancer patients treated with efaproxiral (Efaproxyn) plus whole-brain radiation therapy for brain metastases. Am. J. Clin. Oncol. 2007, 30, 580-587. [CrossRef] [PubMed]

54. Watanabe, T.; Takeda, T.; Omiya, S.; Hikoso, S.; Yamaguchi, O.; Nakano, Y.; Higuchi, Y.; Nakai, A.; Abe, Y.; Aki-Jin, Y.; et al. Reduction in hemoglobin-oxygen affinity results in the improvement of exercise capacity in mice with chronic heart failure. J. Am. Coll. Cardiol. 2008, 52, 779-786. [CrossRef] [PubMed]

55. Watson, J.C.; Doppenberg, E.M.; Bullock, M.R.; Zauner, A.; Rice, M.R.; Abraham, D.; Young, H.F. Effects of the allosteric modification of hemoglobin on brain oxygen and infarct size in a feline model of stroke. Stroke 1997, 28, 1624-1630. [CrossRef] [PubMed]

56. Abraham, D.J.; Wireko, F.C.; Randad, R.S.; Poyart, C.; Kister, J.; Bohn, B.; Liard, J.F.; Kunert, M.P. Allosteric modifiers of hemoglobin: 2-[4-[[(3,5-Disubstituted anilino)carbonyl]methyl]phenoxy]-2-methylpropionic acid derivatives that lower the oxygen affinity of hemoglobin in red cell suspensions, in whole blood, and in vivo in rats. Biochemistry 1992, 31, 9141-9149. [CrossRef] [PubMed]

57. Randad, R.S.; Mahran, M.A.; Mehanna, A.S.; Abraham, D.J. Allosteric modifiers of hemoglobin. 1. Design, synthesis, testing, and structure-allosteric activity relationship of novel hemoglobin oxygen affinity decreasing agents. J. Med. Chem. 1991, 34, 752-757. [CrossRef] [PubMed]

58. Poyart, C.; Marden, M.C.; Kister, J. Bezafibrate derivatives as potent effectors of hemoglobin. Methods Enzymol. 1994, 232, 496-513. [PubMed]

59. Ross, P.D.; Subramanian, S. Ionic and Non-Ionic Effects on the Solubility of Deoxyhemoglobin S. In Biochemical and Clinical Aspects of hemoglobin Abnormalities; Caughey, W.S., Ed.; Academic Press: New York, NY, USA, 1978; pp. 629-645.

Sample Availability: Samples of the compounds are available from the authors.

(C) 2016 by the authors; licensee MDPI, Basel, Switzerland. This article is an open access article distributed under the terms and conditions of the Creative Commons Attribution (CC-BY) license (http:/ / creativecommons.org/licenses/by/4.0/). 